\title{
Overlapping toxic effect of long term thallium exposure on white mustard (Sinapis alba L.) photosynthetic activity
}

Radosław Mazur ${ }^{1 *}$ D, Monika Sadowska², Łucja Kowalewska ${ }^{3}$, Agnieszka Abratowska ${ }^{4}$, Hazem M. Kalaji ${ }^{5}$, Agnieszka Mostowska ${ }^{3}$, Maciej Garstka and Beata Krasnodębska-Ostręga²

\begin{abstract}
Background: Heavy metal exposure affect plant productivity by interfering, directly and indirectly, with photosynthetic reactions. The toxic effect of heavy metals on photosynthetic reactions has been reported in wide-ranging studies, however there is paucity of data in the literature concerning thallium (TI) toxicity. Thallium is ubiquitous natural trace element and is considered the most toxic of heavy metals; however, some plant species, such as white mustard (Sinapis alba L.) are able to accumulate thallium at very high concentrations. In this study we identified the main sites of the photosynthetic process inhibited either directly or indirectly by thallium, and elucidated possible detoxification mechanisms in S. alba.
\end{abstract}

Results: We studied the toxicity of thallium in white mustard (S. alba) growing plants and demonstrated that tolerance of plants to thallium (the root test) decreased with the increasing $T I(I)$ ions concentration in culture media. The root growth of plants exposed to TI at $100 \mathrm{\mu g} \mathrm{L}^{-1}$ for 4 weeks was similar to that in control plants, while in plants grown with $\mathrm{Tl}$ at $1,000 \mathrm{\mu g} \mathrm{L}^{-1}$ root growth was strongly inhibited. In leaves, toxic effect became gradually visible in response to increasing concentration of Tl $\left(100-1,000 \mu \mathrm{g} \mathrm{L}^{-1}\right)$ with discoloration spreading around main vascular bundles of the leaf blade; whereas leaf margins remained green. Subsequent structural analyses using chlorophyll fluorescence, microscopy, and pigment and protein analysis have revealed different effects of varying $\mathrm{Tl}$ concentrations on leaf tissue. At lower concentration partial rearrangement of the photosynthetic complexes was observed without significant changes in the chloroplast structure and the pigment and protein levels. At higher concentrations, the decrease of PSI and PSII quantum yields and massive oxidation of pigments was observed in discolored leaf areas, which contained high amount of TI. Substantial decline of the photosystem core proteins and disorder of the photosynthetic complexes were responsible for disappearance of the chloroplast grana.

Conclusions: Based on the presented results we postulate two phases of thallium toxicity on photosynthesis: the nondestructive phase at early stages of toxicant accumulation and the destructive phase that is restricted to the discolored leaf areas containing high toxicant content. There was no distinct border between the two phases of thallium toxicity in leaves and the degree of toxicity was proportional to the migration rate of the toxicant outside the vascular bundles. The three-fold (nearly linear) increase of TI(I) concentration was observed in damaged tissue and the damage appears to be associated with the presence of the oxidized form of thallium - Tl(III).

Keywords: Thallium, Heavy metal toxicity, Sinapis alba L., Mustard plant, Chlorophyll fluorescence imaging, Photosynthetic complexes, Chemical speciation, Tolerance index

(Continued on next page)

\footnotetext{
* Correspondence: rmazur@biol.uw.edu.pl

'Department of Metabolic Regulation, Faculty of Biology, University of

Warsaw, Miecznikowa 1, 02-096 Warsaw, Poland

Full list of author information is available at the end of the article
} 


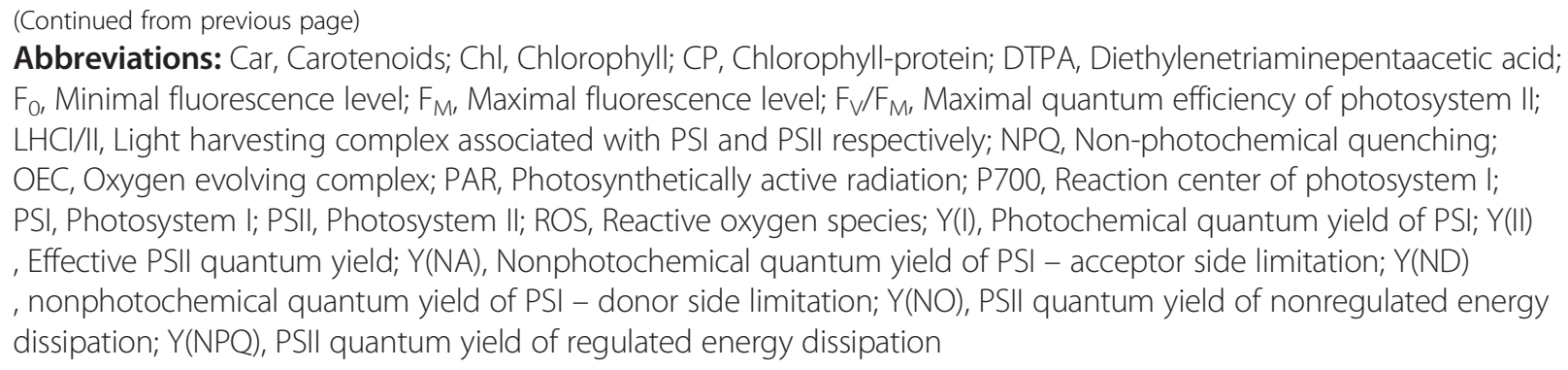

\section{Background}

Light-driven photochemical reactions in higher plants take place in the chlorophyll-protein (CP) complexes localized inside thylakoids, the internal membrane system of chloroplast [1-3]. Core complexes of photosystems I and II (PSI/II) are associated with the respective antennae $(\mathrm{LHCI} / \mathrm{II})$ creating the appropriate supercomplexes: LHCII-PSII and LHCI-PSI. The LHCII-PSII and the trimeric complexes of LHCII are localized in stacked regions of the thylakoid membranes (grana), while the LHCI-PSI is exclusively present in unstacked, stroma thylakoids connecting the grana [4-6].

Heavy metals affect plant productivity by interfering with photosynthesis in all aspects of this process and there is a large body of evidence indicating that there is a direct effect of heavy metals on the photochemical reactions. Heavy metals, if present in excessive amount, affect proteins and their functions through binding to histidine, tryptophan and tyrosine residues or disturb the photochemical function of $\mathrm{CP}$ complexes by interacting with functional metals and in consequence affecting the photosynthetic electron flow [7-10]. Surplus of heavy metals in the cells leads to damages of the photosynthetic pigments due to a substitution of their central atoms. For example the $\mathrm{Hg}$ ions can substitute $\mathrm{Cu}$ ions in plastocyanin, while $\mathrm{Cu}$ or $\mathrm{Cd}$ ions can replace $\mathrm{Mg}$ in the chlorophyll molecules. Inhibition of enzymatic reactions can also be caused by substitution of enzyme cofactors by heavy metal ions. The $\mathrm{Cd}$ ions can substitute $\mathrm{Ca}^{2+}$ in the Oxygen Evolving Complex (OEC) and can interact with the non-heme Fe ions on the acceptor side of the PSII. Furthermore, the loss of the extrinsic proteins of OEC is a result of the direct action of $\mathrm{Cu}(\mathrm{II})$ [11]. $\mathrm{Cu}, \mathrm{Cd}, \mathrm{Pb}$ and $\mathrm{Zn}$ ions affect the photosynthetic efficiency indirectly by inhibiting enzymes responsible for the chlorophyll synthesis, RuBisCo and other Calvin cycle enzymes [8, 11]. Qualitative composition and quantitative content of carotenoids, both essential for the photochemical functions of $\mathrm{CP}$ complexes and the stability of thylakoid membranes, were influenced by an excess of $\mathrm{Cu}$ and $\mathrm{Cd}$ ions $[8,11-13]$. Moreover, the indirect effect of heavy metals was observed on the chloroplast proteome, with varying protein composition and stability of CP complexes $[9,14]$. In mustard plants the excess of $\mathrm{Cd}$ ions was reported to cause a marked decrease in the LHCII and ATP-ase subunit levels [15], while in rye a decrease in the molecular mass of Lhcb1 and Lhcb2 proteins was observed [13]. $\mathrm{Cd}$ and $\mathrm{Cu}$ ions had opposite effect (a decrease by $\mathrm{Cd}$ and an increase by $\mathrm{Cu}$ ) on the LHCII aggregation due to changes in the protein and xanthophyll composition of complexes, respectively [13]. These opposite effects of the $\mathrm{Cd}$ and $\mathrm{Cu}$ toxicants suggest a complex and intricate inhibitory mechanism of heavy metal action. So far, there is very limited data on direct and indirect action of thallium on the photosynthetic apparatus in higher plants.

The influence of heavy metals on the ultrastructure of cells has been also intensively investigated. Distortion of the chloroplast structure by heavy metals was manifested by changes in size and stacking of grana, by thylakoid swelling, and also by the plastoglobule and starch accumulation [8]. Disintegration of the thylakoid membranes may be partially related to an enhanced lipoxygenase activity and a reduction of the galactolipid level [8]. Furthermore, the heavy metals, by inducing generation of the reactive oxygen species, influenced the lipid peroxidation [7], which might cause the disturbance of thylakoid structure [11]. Additionally, the quantitative and qualitative changes in composition of CP complexes [13] might result in a noticeable disorder of the thylakoid structure.

Thallium ( $\mathrm{Tl})$ is a natural trace element, widely distributed in Earth's crust, found in small amounts in sulfide $(\mathrm{Fe}, \mathrm{Zn}, \mathrm{Cu}, \mathrm{Pb})$ and selenite ores $(\mathrm{Cu}, \mathrm{Ag})$. Major anthropogenic sources of thallium pollution are mining, flotation treatment and smelting and areas of relatively high content of thallium are found all over the world, for example in Poland [16], Italy [17, 18], Spain [19], Turkey [20], Chile [21] and China [22]. Thallium is considered to be one of the most toxic of heavy metals [23]. It does not have a known biological function and seems not to be an essential element for life. Thallium is a chemical analogue of potassium and the mechanism of its toxicity as $\mathrm{Tl}^{+}$is that it can substitute $\mathrm{K}^{+}$due to a similar ionic radii of both ions [24].

Elevated concentrations of $\mathrm{Tl}$ were found in tissues of organisms living in the areas polluted with the toxicant 
$[25,26]$. Some of the plants, especially species of the Brassicaceae family are able to hyperaccumulate $\mathrm{Tl}$ ions and the accumulation ranged from up to $1,489 \mathrm{mg} \mathrm{Tl} \mathrm{kg}^{-1} \mathrm{DW}$ in shoots of Silene latifolia [27] and $2,810 \mathrm{mg} \mathrm{Tl} \mathrm{kg}^{-1} \mathrm{DW}$ in Iberis intermedia [28-30], to $15,200 \mathrm{mg} \mathrm{Tl} \mathrm{kg}^{-1} \mathrm{DW}$ in Biscutella laevigata [17, 31, 32]. High ability of crop plants such as Armoracia rusticana [33], Sinapis alba [34, 35], and Brassica sp. [36, 37] to accumulate Tl has been demonstrated and threshold concentration of $\mathrm{Tl}$ hyperaccumulation in shoots was recently established at $100 \mathrm{mg} \mathrm{Tl}$ $\mathrm{kg}^{-1}$ DW [38]. However, the investigated crop species accumulated $\mathrm{Tl}$ under laboratory conditions and none of them colonized Tl-enriched soils and they cannot be considered as Tl hyperaccumulators. High accumulation of thallium was also observed in Iberis intermedia grown in soil spiked with $\mathrm{TlCl}$ solution [39].

Elevated concentration of thallium induced oxidative stress resulting in damage to lipids and proteins [40-42], but the mechanism of the toxicant action is far from being elucidated. In contrast to wide-ranging studies of the effect of other heavy metals toxicity on photosynthetic reactions [9], there is paucity of data in the literature concerning thallium effects in higher plants. Aoki et al. [41] investigated Tl-induced changes in unicellular freshwater cyanobacteria (Synechocystis sp.) - an accepted model organism in studies on the photosynthesis. In this organism the integrity of the photosynthetic apparatus was affected by $\mathrm{Tl}$ exposure with observable fragmentation of thylakoid membranes and accumulation of $\mathrm{Tl}$ in cells. These changes were accompanied by markedly decreased photosynthetic activity of cells [41].

The aim of this investigation was to identify the main sites of the photosynthetic process in leaves of white mustard, which may be directly or indirectly inhibited by $\mathrm{Tl}$. The ultrastructure, pigment and protein composition comparisons and low-temperature fluorescence analyses in $\mathrm{Tl}$ affected plants enabled identification of quantitative and qualitative re-arrangements in the thylakoids and $\mathrm{CP}$ complexes in response to the toxicant. The functionality of PSII and PSI as well as layout of PSII inhibition were assayed by measuring the photosystem photochemistry using a modulated fluorescence or absorbance and fluorescence imaging on the leaf surface. Relations between structural and functional data as well as probable mechanisms of thallium action, such as the importance of the $\mathrm{Tl}(\mathrm{I})$ and $\mathrm{Tl}(\mathrm{III})$ ions are discussed in detail.

\section{Methods}

\section{Plant growth conditions}

Plant cultivation was carried out in a growth chamber at $22{ }^{\circ} \mathrm{C} / 20{ }^{\circ} \mathrm{C}$ (day/night) with $16 \mathrm{~h}$ photoperiod at $100 \mu \mathrm{mol}$ of photons $\mathrm{m}^{-2} \mathrm{~s}^{-1}$ of photosynthetically active radiation (PAR). White mustard (Sinapis alba L. cv. Maryna) seeds (from Agro-land S.C., Wróblewskiego 19 St., 93-578 Łódź,
Poland) were sown in an artificial medium (glass balls) and seedlings at cotyledon stage were placed in $11 \mathrm{~L}$ pots (24 plants per pot) filled with aerated liquid nutrient solution containing: $3 \mathrm{mM} \mathrm{Ca}\left(\mathrm{NO}_{3}\right)_{2}, 1.5 \mathrm{mM} \mathrm{KNO}_{3}, 1.2 \mathrm{mM}$ $\mathrm{MgSO}_{4}, 1.1 \mathrm{mM} \mathrm{KH_{2 }} \mathrm{PO}_{4}, 0.1 \mathrm{mM} \mathrm{C}{ }_{10} \mathrm{H}_{12} \mathrm{~N}_{2} \mathrm{O}_{8} \mathrm{FeNa}$,

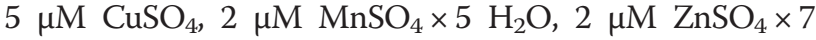
$\mathrm{H}_{2} \mathrm{O}$, and $15 \mathrm{nM}\left(\mathrm{NH}_{4}\right)_{6} \mathrm{Mo}_{7} \mathrm{O}_{24} \times 4 \mathrm{H}_{2} \mathrm{O}, \mathrm{pH}$ 6.0-6.5. Thallium (in a form of $\mathrm{TlNO}_{3}$ ), in amounts of 0 (control cultivation), 100, 500 and 1,000 $\mu \mathrm{g} \mathrm{L}^{-1}$, was added to the nutrient solution. Nutrient solution was refilled, if necessary, without additional dose of thallium during the cultivation. After 4 weeks the plants were harvested. This time period corresponded to full vegetative growth of control plants just before appearance of flower buds. The healthy leaves from plants grown in the presence of $100 \mu \mathrm{g} \mathrm{L}{ }^{-1} \mathrm{Tl}$ were denoted as $\mathrm{H} 100$. The leaves of plants cultivated in the presence of $500 \mu \mathrm{g} \mathrm{L}^{-1} \mathrm{Tl}$ were divided into three groups: $(i)$ healthy green leaves, which showed no changes in morphology in comparison with that of leaves of the control cultivation ( $\mathrm{H} 500)$; ( $i i)$ green parts of the affected leaves (G500) and (iii) yellow parts of the affected leaves (Y500). Similar classification was applied to the leaves from plants grown in the presence of $1,000 \mu \mathrm{g} \mathrm{L}^{-1} \mathrm{Tl}$ (G1000 and Y1000).

\section{Determination of the root tolerance index}

The degree of tolerance to $\mathrm{Tl}$ was determined using the root tolerance index $[43,44]$. The length of the root of each plant was measured with a millimeter ruler. The measurements started before thallium salt was added to the medium and were repeated every three days until the end of the cultivation (i.e., to the harvesting). On the basis of measurements, the tolerance index (IT) (the growth of roots of plants exposed to thallium, expressed as a percentage of control roots growth) was calculated.

The concentration of $\mathrm{Tl}$ in mineral medium was monitored regularly during the experiment. A volume of $10 \mathrm{~mL}$ of medium was taken from each container and analyzed by the ICP MS technique as described below. Initial concentration of $\mathrm{Tl}$ was measured immediately after Tl salt was added to the containers and the measurement was repeated weekly through the cultivation.

\section{Microscopic observations}

Samples of $3 \mathrm{~mm}^{2}$ were cut from middle parts of the leaves. These samples were fixed in $2.5 \%(\mathrm{w} / \mathrm{v})$ glutaraldehyde in $50 \mathrm{mM}$ cacodylate buffer $(\mathrm{pH} 7.4)$ for $2 \mathrm{~h}$, washed with the fixing buffer and placed in a $2 \%(\mathrm{w} / \mathrm{v})$ $\mathrm{OsO}_{4}$ in $50 \mathrm{mM}$ cacodylate buffer ( $\mathrm{pH}$ 7.4) for approximately $12 \mathrm{~h}$ at $4{ }^{\circ} \mathrm{C}$. Specimens dehydrated in a graded acetone series, were embedded in a low viscosity epoxy resin and cut on a Leica UCT ultramicrotome. Semithin sections of $250 \mathrm{~nm}$ thick and ultrathin sections of $70 \mathrm{~nm}$ were used for light and transmission electron 
microscopy (TEM), respectively. For TEM technique the ultrathin sections were stained with uranyl acetate and examined with a JEM 1400 electron microscope (Jeol, Japan) of the Nencki Institute of Experimental Biology of the Polish Academy of Sciences, Warsaw. For bright field light microscopy the semi-thin sections were stained in $0.5 \%(\mathrm{w} / \mathrm{v})$ toluidine blue water solution and examined with a Zeiss AxioLab A1 microscope equipped with Zeiss A-Plan $20 \times(\mathrm{NA}=0.65) \mathrm{Ph} 2$ objective lens.

\section{Chlorophyll $a$ fluorescence imaging}

Leaf fluorescence images were recorded with FluorCam FC 800-C (Photon System Instruments, Brno, Czech Republic). Leaves from dark adapted plants for $30 \mathrm{~min}$ were detached immediately prior placing them on tray in a FluorCam chamber. The fluorescence images were recorded with $512 \times 512$ pixels resolution with camera parameters set to avoid saturation of CCD wells. After $\mathrm{F}_{0}$ and $\mathrm{F}_{\mathrm{M}}$ determination $(0.8 \mathrm{~s}$ saturation pulse with $4,000 \mu \mathrm{mol}$ photons $\mathrm{m}^{-2} \mathrm{~s}^{-1}$ ) and $30 \mathrm{~s}$ dark relaxation the actinic light $\left(50 \mu \mathrm{mol}\right.$ photons $\left.\mathrm{m}^{-2} \mathrm{~s}^{-1}\right)$ was on and five saturation pulses at constant time intervals were applied. After $120 \mathrm{~s}$ actinic light was turned off and one additional saturation pulse, during $20 \mathrm{~s}$ dark relaxation, was applied. At all saturation pulses the $\mathrm{F}_{\mathrm{M}}$ ' values were measured. The recorded data were analyzed with FluorCam v7.0 software. The maximal quantum efficiency of PSII $\left(F_{V} / F_{M}\right)$ was calculated from the formula $\left(F_{0}-F_{M}\right) / F_{M}$ and the non-photochemical quenching parameter (NPQ) from the formula: $\left(F_{M}-F_{M}{ }^{\prime}\right) / F_{M}$.

\section{Simultaneous chlorophyll $a$ fluorescence and P700 measurements}

Fluorescence measurements were carried out using a pulse-amplitude modulation fluorometer, a Dual-PAM100 (Heinz Walz GmbH, Effeltrich, Germany) and the automated Induction Curve routine provided by the DualPam software, with repetitive application of saturation pulses for assessment of fluorescence and P700 curves, from which the specific parameters of photosystem I (PSI) and photosystem II (PSII) were calculated by the software. Plants were dark adapted for $30 \mathrm{~min}$ prior to all measurements. After $\mathrm{F}_{0}$ (red light pulse with intensity below $1 \mu \mathrm{mol}$ photons $\left.\mathrm{m}^{-2} \mathrm{~s}^{-1}\right), \mathrm{F}_{\mathrm{M}}(0.3 \mathrm{~s}$ red light saturation pulse with $10,000 \mu \mathrm{mol}$ photons $\left.\mathrm{m}^{-2} \mathrm{~s}^{-1}\right)$ and $\mathrm{P}_{\mathrm{M}}(0.3 \mathrm{~s}$ red light saturation pulse with $10,000 \mu \mathrm{mol}$ photons $\mathrm{m}^{-2} \mathrm{~s}^{-1}$ after $10 \mathrm{~s}$ far red light illumination) determination the actinic light $\left(50 \mu \mathrm{mol}\right.$ photons $\left.\mathrm{m}^{-2} \mathrm{~s}^{-1}\right)$ was on and $\mathrm{F}_{\mathrm{M}}$ ' and $\mathrm{P}_{\mathrm{M}}$ ' values were measured by application of series of saturation pulses of identical light intensity $\left(0.3 \mathrm{~s}\right.$ pulse at $10,000 \mu \mathrm{mol}$ photons $\mathrm{m}^{-2} \mathrm{~s}^{-1}$ with $1 \mathrm{~s}$ interval between actinic light on and saturation pulse, and with $20 \mathrm{~s}$ interval between two consecutive saturation pulses).
The effective PSII quantum yield (Y(II)) was calculated according to Genty et al. [45] by the formula: $\mathrm{Y}(\mathrm{II})=\left(\mathrm{F}_{\mathrm{M}}{ }^{\prime}-\mathrm{F}\right) / \mathrm{F}_{\mathrm{M}^{\prime}}$ and measured after dark adaptation when the effective PSII quantum yield is maximal. The value of Y(II) varies between 0 and 1. Kramer et al. [46] introduced two new parameters describing nonphotochemical processes in PSII: $\mathrm{Y}(\mathrm{NPQ})$ and $\mathrm{Y}(\mathrm{NO})$. The first parameter is the yield of regulated energy dissipation in PSII and is related to the xanthophyll cycle activity, whereas the second one, $\mathrm{Y}(\mathrm{NO})$ represents the yield of nonregulated energy dissipation in PSII and accordingly represents the effect of side reactions after prolonged closure of the PSII centers. By definition the sum of all yields always gives unity: $\mathrm{Y}(\mathrm{II})+\mathrm{Y}(\mathrm{NO})+\mathrm{Y}(\mathrm{NPQ})=1$. The photochemical quantum yield of PSI $(\mathrm{Y}(\mathrm{I}))$ is described as the fraction of overall P700 that in a given state is reduced and is not limited by the acceptor side. The Y(I) value was calculated from complementary non-photochemical PSI quantum yields: $\mathrm{Y}(\mathrm{I})=1-\mathrm{Y}(\mathrm{ND})-\mathrm{Y}(\mathrm{NA})$, where $\mathrm{Y}(\mathrm{ND})$ is non-photochemical energy dissipation related to donor side limitation and $\mathrm{Y}(\mathrm{NA})$ is non-photochemical energy dissipation related to acceptor side limitation [47].

\section{$77 \mathrm{~K}$ steady-state fluorescence measurements}

Leaf samples were ground in a mortar in chilled $20 \mathrm{mM}$ HEPES-NaOH buffer (pH 7.5), containing $330 \mathrm{mM}$ sorbitol, $15 \mathrm{mM} \mathrm{NaCl}$ and $4 \mathrm{mM} \mathrm{MgCl}_{2}$. Homogenates were filtered through $100 \mu \mathrm{m}$ nylon mesh, diluted to chlorophyll concentration below $10 \mu \mathrm{g} \mathrm{mL}^{-1}$ and immediately subjected to the fluorescence measurements. Low temperature $(77 \mathrm{~K})$ fluorescence emission spectra were recorded using modified Shimadzu RF-5301PC spectrofluorometer where excitation and emission beams were supplied by optical fibers. Samples were placed in a polytetrafluoroethylene cuvette and submerged in liquid nitrogen. Excitation wavelength was set at $470 \mathrm{~nm}$, excitation and emission slits at $5 \mathrm{~nm}$ and scans were taken from 600 to $800 \mathrm{~nm}$ through LP600 filter. Due to a decrease in the fluorescence caused by the chlorophyll reabsorption effect, the measured fluorescence was compensated by multiplication by a correction factor: $\operatorname{antilog}{ }_{10}\left(A_{e x} / 2+A_{e m} / 2\right)$, where $A_{e x}$ and $A_{e m}$ are sample absorption at the excitation and emission wavelength respectively [48].

\section{Pigments extraction and analysis}

Chlorophyll concentration was measured directly in leaf blade using SPAD-502 chlorophyll meter (Konica Minolta, Japan) as well as by spectroscopic measurements following extraction with $80 \%$ acetone [49]. For further analysis of carotenoids and chlorophylls by UPLC MS, a multi-step extraction procedure was applied as described previously [50]. 
Extracted pigments were separated using Acquity Ultra Performance LC system (Waters) connected with Synapt G2 HDMS mass spectrometer (Waters). The samples were injected $(7.5 \mu \mathrm{L})$ into an Acquity UPLC HSS T3 $(1.8 \mu \mathrm{m}, 1.0 \times 150 \mathrm{~mm})$ analytical column equilibrated in $100 \%$ of solvent A (water/methanol, 15/85; v/v). The column was washed for $100 \mathrm{~min}$ at a constant flow rate of $35 \mu \mathrm{L} \mathrm{min}{ }^{-1}$ with $100 \%$ of solvent A at $25{ }^{\circ} \mathrm{C}$. Samples were fractionated with the step gradient of buffer B (methanol/2-propanol/hexane, 2/1/1; v/v) in buffer A as follows: $0-15 \% \mathrm{~B}$ in the $100-160 \mathrm{~min}$ (flow rate $35 \mu \mathrm{L} \mathrm{min}{ }^{-1}$ ); $15-80 \% \mathrm{~B}$ in $160-240 \mathrm{~min}$ (flow rate 35 $20 \mu \mathrm{L} \mathrm{min} \operatorname{mos}^{-1}$ ); $80-90 \% \mathrm{~B}$ in $240-245 \mathrm{~min}$ (flow rate $20 \mu \mathrm{L} \mathrm{min}{ }^{-1}$ ); $90-100 \%$ B in 245-250 min (flow rate 20$80 \mu \mathrm{L} \mathrm{min} \mathrm{m}^{-1}$ ) and hold for $10 \mathrm{~min}$ at $100 \% \mathrm{~B}$. In the next 5 min concentration of solvent $B$ was decreased to $0 \%$ and the column was equilibrated for $10 \mathrm{~min}$ with $100 \%$ buffer A (flow rate $80 \mu \mathrm{L} \mathrm{min}{ }^{-1}$ ) before the next injection. Fractionation of samples was monitored by a photodiode array detector at $200-750 \mathrm{~nm}$ range and mass spectrometer at $200-1000 \mathrm{~m} / \mathrm{z}$ range. For better ionization efficiency the column eluate was mixed with $\mathrm{LiOH}$ solution (50 $\mathrm{mM}$ in methanol/water, 39/1; v/v) distributed by an external syringe pump (flow rate $\left.2 \mu \mathrm{L} \min ^{-1}\right)$. The mass accuracy of the raw data was corrected using leucine enkephalin standard [51] that was used as a lock mass during sample analysis. For quantification the single chromatogram at $436 \mathrm{~nm}$ (characteristic for carotenoids) was extracted and integrated using MassLynx 4.1 software (Waters).

\section{SDS-PAGE and Western-blot analysis}

For electrophoretic analysis leaf extracts were prepared with Laemmli Sample Buffer (Bio-Rad Laboratories, USA) and samples containing $0.25 \mu \mathrm{g}$ of chlorophyll were separated on a $14 \%(\mathrm{w} / \mathrm{v})$ polyacrylamide gels. SDS-PAGE and Western-blot analysis were performed as described by Janik et al. [52]. Briefly, following separation by SDS-PAGE and electrotransfer onto the polyvinylidene fluoride (PVDF) membrane, the specific polypeptides were detected with primary antibodies (all raised in rabbits, from Agrisera, Sweden): Lhcb1 (AS01 004), Lhcb2 (AS01 003), D1 (AS10 704), D2 (AS06 146), CP43 (AS11 1787), PsbO (AS05 092), Lhcal (AS01 005), PsaA (AS06 172) followed by anti-rabbit horseradish peroxidase conjugate and ECL Detection System (Bio-Rad Laboratories, USA). Immediately after detection the membrane was stripped by incubation $\left(2 \times 15 \mathrm{~min}, 55^{\circ} \mathrm{C}\right.$ with shaking) in $62.5 \mathrm{mM}$ Tris- $\mathrm{HCl}$ (pH 6.8) buffer containing $2 \%$ (w/v) SDS and $100 \mathrm{mM} \mathrm{2-}$ mercaptoethanol and washed in $20 \mathrm{mM}$ Tris- $\mathrm{HCl}$ buffer (pH 7.5), containing $0.5 \mathrm{M} \mathrm{NaCl}$ and $0.1 \%(\mathrm{v} / \mathrm{v})$ Tween 20. Subsequently the reaction with the new set of antibodies with the same detection system was performed.

\section{Determination of total thallium concentration}

The leaves were air dried $\left(55-60{ }^{\circ} \mathrm{C}\right)$ and homogenized using agate ball mill. The samples were digested in nitric acid (200 mg in $3 \mathrm{~mL}$ conc. $\mathrm{HNO}_{3}$ ). The mineralization was carried out in a closed system with automatic temperature control (Ethos 1600 Milestone, Italy). Microwave energy of $1,000 \mathrm{~W}$ was applied. The temperature control settings were as follows: $5 \mathrm{~min}, 90{ }^{\circ} \mathrm{C} ; 10 \mathrm{~min}$, $170{ }^{\circ} \mathrm{C} ; 45 \mathrm{~min}, 200{ }^{\circ} \mathrm{C}$. Following digestion the samples were diluted with water to the total volume of $25 \mathrm{~mL}$ and analyzed by ELAN 6100 DRC ICP mass spectrometer (PE-SCIEX, Canada). Nutrient solutions were diluted 10 or 100 fold with water and also analyzed by ICP MS. Measurements were performed applying the following experimental parameters: sweep: 5; number of replicates: 5; dwell time: $0.1 \mathrm{~s}$; ICP RF power: 1,100 W; lens voltage: $12 \mathrm{~V}$; nebulizer gas flow: $0.95 \mathrm{~L} \mathrm{~min}{ }^{-1}$; plasma gas flow: 13.3 $\mathrm{L} \mathrm{min}^{-1}$; and monitored isotopes: ${ }^{203} \mathrm{Tl}$ and ${ }^{205} \mathrm{Tl}$. Quantitative Analysis program was used to automatically correct the intensities of interfering isobaric and molecular ions. For quantitative determinations the calibration curve method was applied. The signal intensity drift was controlled by determination of a standard solution after analysis of 5-10 samples.

\section{Thallium speciation analysis}

Selected leaf tissues were ground to a fine powder in liquid nitrogen and extracted with $100 \mathrm{mM}$ ammonium acetate, $5 \mathrm{mM}$ diethylenetriaminepentaacetic acid (DTPA) solution $\mathrm{pH} 6.2$; $1 \mathrm{~g}$ of plant material in $8 \mathrm{~mL}$ of extraction solution was shaken for $1 \mathrm{~h}$ at $37{ }^{\circ} \mathrm{C}$. The extracts were clarified by centrifugation at $21,000 \mathrm{~g}$ for $30 \mathrm{~min}$ and the supernatant was diluted 10fold with the extraction solution. Nutrient solutions were diluted 10 fold with the extraction solution to conserve thallium speciation. Thallium species were separated on a size exclusion column Superdex Peptide 10/ $300 \mathrm{GL}(13 \mu \mathrm{m}, 10 \times 310 \mathrm{~mm})$, using $1200 \mathrm{HPLC}$ pump (Agilent) with injection valve model 7725 and a $100 \mu \mathrm{L}$ injection loop (Rheodyne, Cotati). Mobile phase was $100 \mathrm{mM}$ ammonium acetate with $5 \mathrm{mM}$ DTPA, pH 6.2, at a flow rate of $0.75 \mathrm{~mL} \mathrm{~min}{ }^{-1} \cdot{ }^{203} \mathrm{Tl}$ and ${ }^{205} \mathrm{Tl}$ were detected on-line by ELAN 6100 DRC ICP mass spectrometer (PESCIEX, Canada) with a concentric nebulizer. Measurements were performed with the following experimental parameters: nebulizer gas flow $0.84 \mathrm{~L} \mathrm{~min}^{-1}$, auxiliary gas flow $1.2 \mathrm{~L} \mathrm{~min}^{-1}$, plasma gas flow $14.5 \mathrm{~L} \mathrm{~min}^{-1}$, ICP RF power $1,000 \mathrm{~W}$, sweeps/reading 1 , readings/replicate 14,000 , replicates 1 , dwell time $100 \mathrm{~ms}$.

\section{Analysis of the results}

For determination of the statistical significance of the differences between groups two types of statistical analysis were performed. For root tolerance index data $(n=24)$ the ANOVA analysis with post-hoc Tukey test at $p=0.05$ was 
used. For the rest of the data where the number of replicates between the groups was different ( $\mathrm{n}$ between 3 and 10, details in figure legends) the non-parametric KruskallWallis analysis with post-hoc Mann-Whitney test at $p=$ 0.05 was employed. All analyses were carried out using Statistica 9.1 software package (Statsoft Inc., USA).

\section{Results}

\section{Tolerance to thallium}

The root tolerance test revealed that exposure of plants to each of the applied concentrations of $\mathrm{Tl}$ resulted in clearly different effects. These differences were already noticeable after the first week of the exposure and became more pronounced during the course of the experiment (Fig. 1a). At $100 \mu \mathrm{g} \mathrm{L}^{-1}$ exposure, growth of roots was strongly inhibited only at the beginning of cultivation (IT value was on average $28 \%$ of control) and after the third week of experiment root growth rate did not differ from that of the control (Fig. 1a), and the amount of $\mathrm{Tl}$ in the medium decreased by a half during the course of the experiments (four weeks; Fig. 1b). These observations indicated that $S$. alba plants taken up $\mathrm{Tl}$ from the medium and tolerated well the exposure to the toxicant at $100 \mu \mathrm{g} \mathrm{L}^{-1}$. The root tolerance index at the concentration of $500 \mu \mathrm{g} \mathrm{L}{ }^{-1}$ was at the level of $30-45 \%$ of control but it increased during the last week of cultivation. The difference in IT index at $500 \mu \mathrm{g} \mathrm{L}^{-1}$ was statistically significant in comparison with IT indices for 100 and $1000 \mu \mathrm{g} \mathrm{L}{ }^{-1}$ exposures (Fig. 1a). At $500 \mu \mathrm{g} \mathrm{L}-1$ exposure the plants taken up approximately $25 \%$ of $\mathrm{Tl}$ from the medium and exhibited moderate toxicity. The initial concentration of $500 \mu \mathrm{g} \mathrm{L}{ }^{-1}$ of $\mathrm{Tl}$ was reduced by $25 \%$ during four weeks (Fig. 1b). At the concentration of $1000 \mu \mathrm{g} \mathrm{L}^{-1}$ of $\mathrm{Tl}$, the growth of roots was strongly inhibited during the whole time of experiment and the IT index decreased to $12-15 \%$ of control, indicating strong toxicity to $S$. alba (Fig. 1a). In this case the decrease of $\mathrm{Tl}$ concentration in the medium was the smallest (Fig. 1b).

\section{Changes in leaf morphology under thallium exposure}

White mustard plants grown in the presence of $\mathrm{Tl}$ in a hydroponic solution exhibited many morphological defects (Additional file 1: Figure S1). However, these defects were visible only at higher concentrations of $\mathrm{Tl}$, while plants exposed to $100 \mu \mathrm{g} \mathrm{L}{ }^{-1}$ of $\mathrm{Tl}$ were not morphologically different from the control plants (Additional file 1: Figure S1A, B). The plants exposed to $500 \mu \mathrm{g} \mathrm{L}{ }^{-1} \mathrm{Tl}$ were much smaller and a half of them showed changes in the leaf blade morphology with discoloration along the midribs and the main nerves, and deformation of the margins (Additional file 1: Figure S1C). At $1000 \mu \mathrm{g} \mathrm{L}^{-1}$ the plant growth was highly inhibited - plants developed only six strongly deformed leaves; control plants had nine leaves. Progressive discoloration areas and necrotic regions were visible on the surface of the older leaves (Additional file 1: Figure S1D). Moreover, approximately $15 \%$ of seedlings did not survive exposure to $\mathrm{Tl}$ at $1,000 \mu \mathrm{g} \mathrm{L} \mathrm{L}^{-1}$.

\section{Total concentration and chemical speciation of thallium}

The total concentration of $\mathrm{Tl}$ in leaves increased with the increase of $\mathrm{Tl}$ concentration in the nutrient solution (Fig. 2a). For plants grown in the presence of $500 \mu \mathrm{g} \mathrm{L} \mathrm{L}^{-1}$ $\mathrm{Tl}$, the concentration of $\mathrm{Tl}$ in healthy leaves (H500) and in green parts of the affected leaves (G500) was similar. The yellow parts of leaves (Y500) accumulated almost twice as much $\mathrm{Tl}$ as the green parts (H500 and G500).

Thallium is present in the environment in two redox states, namely $\mathrm{Tl}(\mathrm{I})$ and $\mathrm{Tl}(\mathrm{III})$. Chemical speciation analysis of $\mathrm{Tl}$ in leaf extracts was performed using HPLC with a size exclusion column (SEC). An example of this analysis is presented in Fig. 2b where the first signal corresponds to $\mathrm{Tl}(\mathrm{III})$, detected as a higher mass complex with DTPA and the second signal for free ions of $\mathrm{Tl}(\mathrm{I})$.
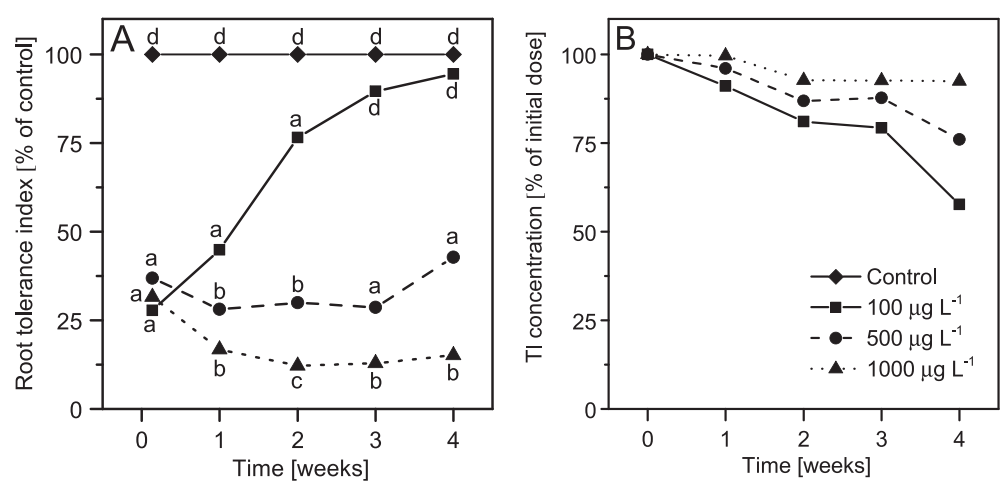

Fig. 1 Tolerance of $S$. alba to different concentrations of TI. a Tolerance index (IT) of S. alba to TI during 4 weeks of cultivation. Mean values of IT among groups (control group is $100 \%$ every time) denoted by the same letter did not differ significantly at $p=0.05$ ( $n=24$, for clear picture the SD values were omitted). $\mathbf{b}$ total TI concentration in mineral medium during 4 weeks of cultivation expressed as a $\%$ of an initial dose and measured by ICP MS 

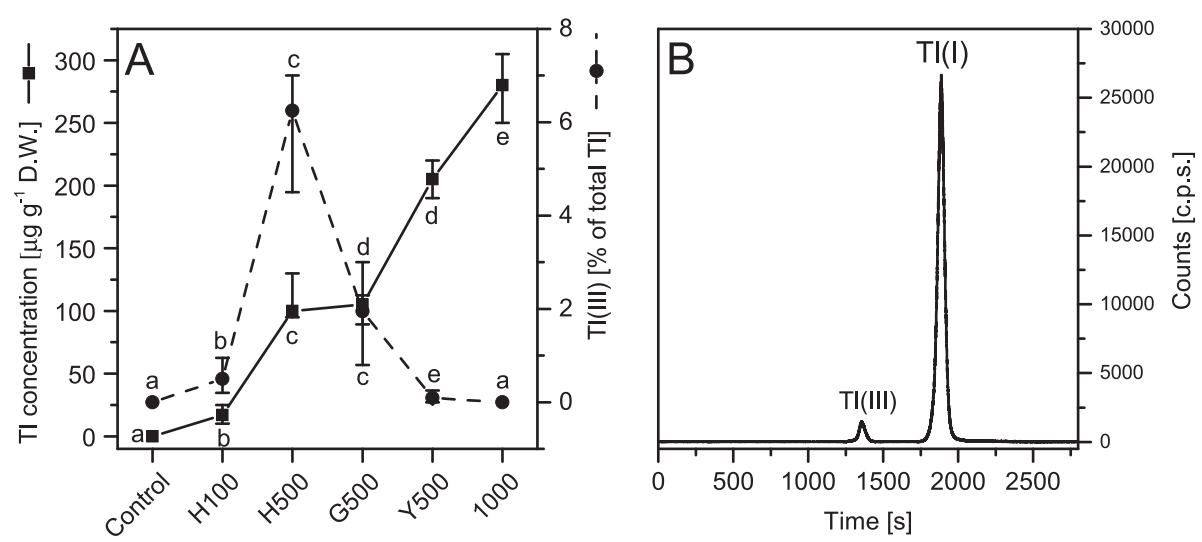

Fig. 2 Analysis of thallium accumulation and speciation in S. alba leaves. a Total TI concentration (solid line with full squares) and the contribution of $\mathrm{Tl}(\mathrm{III})$, expressed as a \% of total TI content, (dashed line with full circles) in leaves of white mustard grown in control and 100 (H100), 500 (H500, healthy green leaves; G500 and Y500, green and yellow parts of the affected leaves) and 1,000 $\mathrm{g} \mathrm{L} \mathrm{L}^{-1}$ of TI. Values are medians from three to four replicates and whiskers show the range of the data. Values denoted by the same letter did not differ significantly at $p=0.05$. $\mathbf{b}$ An example of SEC ICP MS chromatogram of white mustard leaf extract (H500). Mobile phase: $100 \mathrm{mM}$ ammonium acetate with $5 \mathrm{mM} \mathrm{DTPA}, \mathrm{pH} 6.2$; flow rate $0.75 \mathrm{~mL} \mathrm{~min}^{-1}$; detected isotope: ${ }^{205} \mathrm{Tl}$

In each sample the dominating ion form was $\mathrm{Tl}(\mathrm{I})$, but noticeable amounts of $\mathrm{Tl}(\mathrm{III})$ were also detected: $0.5 \%$ of total $\mathrm{Tl}$ concentration in $\mathrm{H} 100,6 \%$ in $\mathrm{H} 500,1.9 \%$ in G500 and $0.1 \%$ in Y500. In leaves grown in the presence of $1,000 \mu \mathrm{g} \mathrm{L} \mathrm{L}^{-1} \mathrm{Tl}$ only trace amounts (not sufficient for quantitative determination) of $\mathrm{Tl}(\mathrm{III})$ were found (Fig. 2a).

Additionally, speciation of $\mathrm{Tl}$ was determined in nutrient solutions, which originally contained $\mathrm{Tl}(\mathrm{I})$ only. Samples of nutrient solutions were collected at the same time as the plants were harvested. Samples were diluted (1:9) with a mobile phase solution in order to conserve chemical speciation of $\mathrm{Tl}$. $\mathrm{Tl}(\mathrm{III})$ was not detected in samples prepared in this way - after several weeks of the plant cultivation all nutrient solutions still contained only $\mathrm{Tl}(\mathrm{I})$.

\section{Changes in leaf blade anatomy}

Additional analysis of the leaf blade anatomy by light and electron microscopy was also performed in attempt to explain morphological changes and discoloration of leaves on plants grown in the presence of 500 and $1,000 \mu \mathrm{g} \mathrm{L}^{-1} \mathrm{Tl}$.

Analysis of the leaf blade cross-sections (Additional file 1: Figure S2) showed no significant changes in the cell structure between control and the plants exposed to Tl. However, in leaves of the Y500, G1000 and Y1000 samples there was a higher number of the palisade mesophyll cells, which in these samples formed two quite regular layers whereas in control and in the H100 leaves these cells were irregularly arranged. Higher number of the palisade mesophyll cells resulted in an overall increase of the leaf blade thickness. Detailed analysis of the cell structure by a transmission electron microscopy showed no presence of high electron density deposits usually related to complexes containing heavy metals [53]. No anomalies in structural appearance of nuclei, mitochondria, peroxisomes and endoplasmic reticulum were detected in $\mathrm{Tl}$ treated plants. However, changes in the chloroplast structure emerged with the exposure to increased $\mathrm{Tl}$ concentrations in the nutrient solution (Fig. 3). Chloroplasts in the control plants had a typical structure - thylakoid network was well developed with high number of grana stacks, composed of 10-15 layers on average and connected by unstacked stroma thylakoids (Fig. 3a). Exposure to low concentration of $\mathrm{Tl}\left(100 \mu \mathrm{g} \mathrm{L}{ }^{-1}\right)$ did not affect the thylakoid structure (Fig. 3b) and similarly chloroplasts in H500 and G500 leaf samples showed no changes in the thylakoid membrane organization (Fig. 3c, d). However, in the Y500 samples the chloroplast size was smaller (Fig. 3e) and there was a significant decrease of the thylakoid membrane length as well as dramatic reduction of grana stacks. Chloroplasts in G1000 samples showed no significant changes in the thylakoid structure compared to the control plants (Fig. 3f). However, chloroplasts in the Y1000 samples were much smaller than those present in the control samples. Similar to Y500 in these plants the total length of thylakoid membranes and the number of grana were very low (Fig. 3g) as compared to the control chloroplasts.

\section{Changes in photochemical activity - in vivo fluorescence measurements}

The distribution of chlorophyll fluorescence in the dark adapted plants was analyzed to ascertain how these relate to changes in the chloroplast structure observed at elevated levels of $\mathrm{Tl}$ (Fig. 4). In control leaves (Fig. 4a) the $\mathrm{F}_{0}$ intensity was almost uniformly distributed 

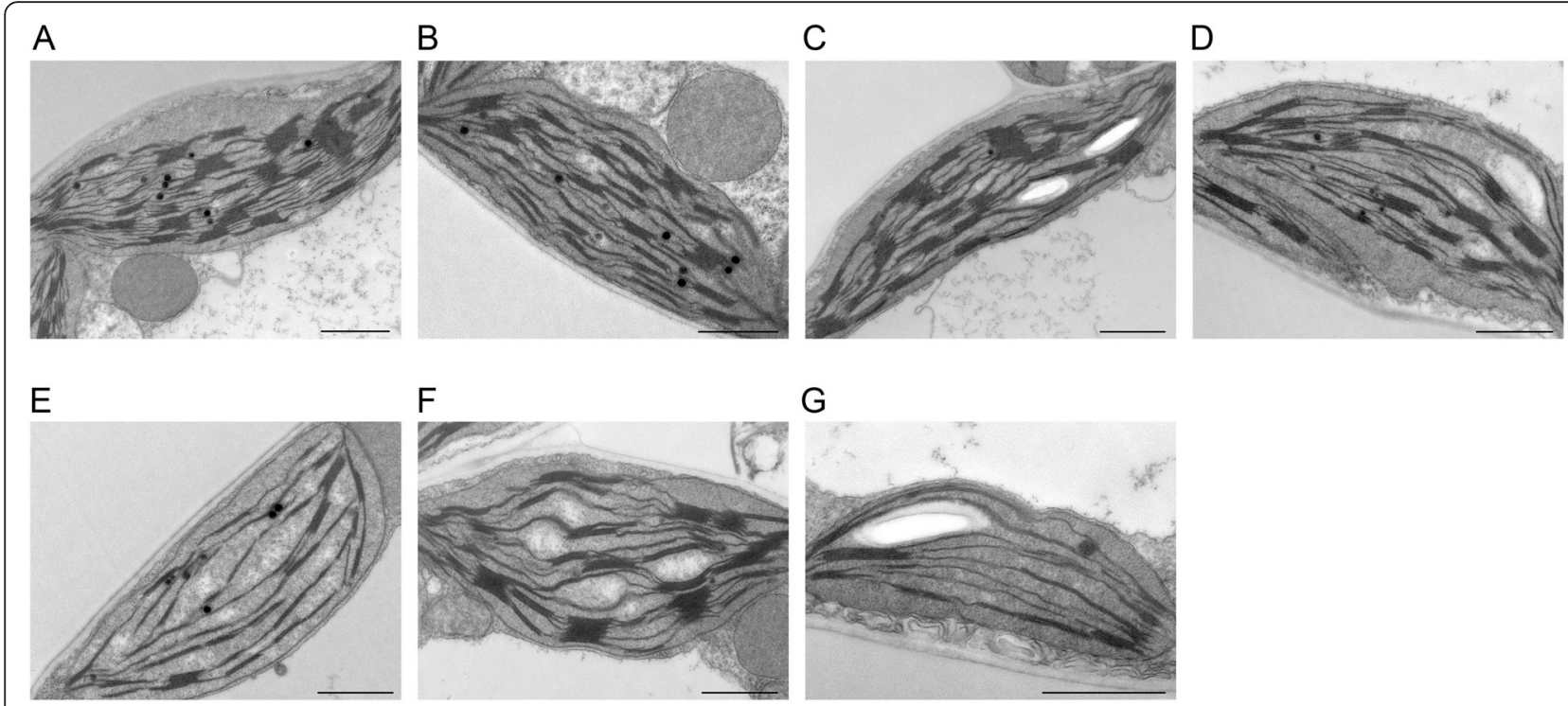

Fig. 3 Changes of mesophyll chloroplast structure of S. alba plants grown in the presence of thallium. TEM images of chloroplasts from control (a) and Tl-treated plants (b-g): $100 \mu \mathrm{g} \mathrm{L}{ }^{-1}$ (H100) (B); $500 \mu \mathrm{g} \mathrm{L}$ healthy green leaves, (H500) (c), green (G500) (d) and yellow (Y500) (e) parts of the affected leaves; 1,000 $\mu \mathrm{g} \mathrm{L}^{-1}$ green (G1000) (f) and yellow (Y1000) $(\mathbf{g})$ parts of the affected leaves. Bar $=1 \mu \mathrm{m}$

throughout the leaf surface and its average intensity was $197 \pm 21$ fluorescence units. Application of the saturation pulse induced a 6 -fold increase in the signal and it reached the maximal fluorescence $\left(\mathrm{F}_{\mathrm{M}}\right)$ level. The calculated maximal quantum efficiency of PSII $\left(\mathrm{F}_{\mathrm{V}} / \mathrm{F}_{\mathrm{M}}\right)$ for the entire leaf had a Gaussian distribution with the maximum at 0.83 , which is a typical value for plants grown in optimal conditions [54]. In $\mathrm{H} 100$ leaves the fluorescence distribution as well as $F_{V} / F_{M}$ value were the same as in the control leaves (Fig. 4b). Elevated concentration of $\mathrm{Tl}$ in leaves influenced both $F_{0}$ and $F_{M}$ in $H 500$ leaves: the value of $F_{0}$ increased in the leaf center, however $F_{M}$ increased as well and as a result the $F_{V} / F_{M}$ was the same as in the control plants (Fig. 4c).

In the morphologically affected leaves from plants grown in the presence of $500 \mu \mathrm{g} \mathrm{L}^{-1} \mathrm{Tl}$ the value of $\mathrm{F}_{0}$ increased gradually from the edge to the center of the leaf blade (Fig. 4d) and reached the level similar to that in the discolored areas of the leaves. Increased intensity of $F_{0}$ strongly influenced the $F_{V} / F_{M}$ value, which had optimal values only at the leaf margin and decreased gradually to 0.70-0.62 in the center (Fig. 4d). In plants exposed to $1,000 \mu \mathrm{g} \mathrm{L} \mathrm{L}^{-1}$ of $\mathrm{Tl}$ the $\mathrm{F}_{0}$ signal was very high (three times more intense than in the controls), especially in the center of the leaf (Fig. 4e) and as a result the observed average $\mathrm{F}_{\mathrm{V}} / \mathrm{F}_{\mathrm{M}}$ values were very low, between 0.30 and 0.67 depending on the analyzed leaf (Fig. 4e).

The decrease of the $F_{V} / F_{M}$ value indicated that the photochemical activity in the $\mathrm{Tl}$ exposed plants was impaired, especially in the discolored areas of the leaves. The photochemical and non-photochemical activity yields in steady state conditions (calculated after the last saturation pulse during the induction curve routine) for PSI and for PSII are presented in Fig. 5a and b, respectively. The photochemical activity of PSI (Y(I)) and PSII (Y(II)) in control plants showed typical values observed in other species $[55,56]$. With increasing concentration of $\mathrm{Tl}$ the $\mathrm{Y}(\mathrm{I})$ and $\mathrm{Y}(\mathrm{II})$ values decreased and reached the minimal values in the Y1000 plant samples (Fig. 5a, b).

The decreasing value of $\mathrm{Y}(\mathrm{I})$ indicated that the excitation energy reaching PSI centers is more effectively converted to heat by non-photochemical process. With increasing $\mathrm{Tl}$ concentration in leaves fluctuations were observed in $\mathrm{Y}(\mathrm{ND})$ and $\mathrm{Y}(\mathrm{NA})$ yields, however, the rising trend for both non-photochemical yields was observed and these reached their maximal values in the Y1000 samples (Fig. 5a).

The decrease of Y(II) yield, similar to Y(I) (Fig. 5b), indicated that the photochemical conversion of the excitation energy that reaches PSII centers was decreasing suggesting that a non-photochemical conversion was more efficient. With the increase of $\mathrm{Tl}$ concentration in leaves the $\mathrm{Y}(\mathrm{NPQ})$ and $\mathrm{Y}(\mathrm{NO})$ values increased together with some fluctuations similar to those for the PSI yields. In $\mathrm{Y} 1000$ samples the $\mathrm{Y}(\mathrm{NPQ})$ yield increased 2fold whereas the increase of $\mathrm{Y}(\mathrm{NO})$ yield was only $20 \%$ higher than that of the controls (Fig. 5b).

The observed increase of PSII non-photochemical yields indicated that the energy conversion at larger $\mathrm{Tl}$ concentration was highly impaired. Therefore an analysis of the fluorescence images was performed to evaluate whether the areas with high level of non-photochemical quenching overlapped with the discolored leaf regions (Additional file 1: Figure S3). Examples of fluorescence 


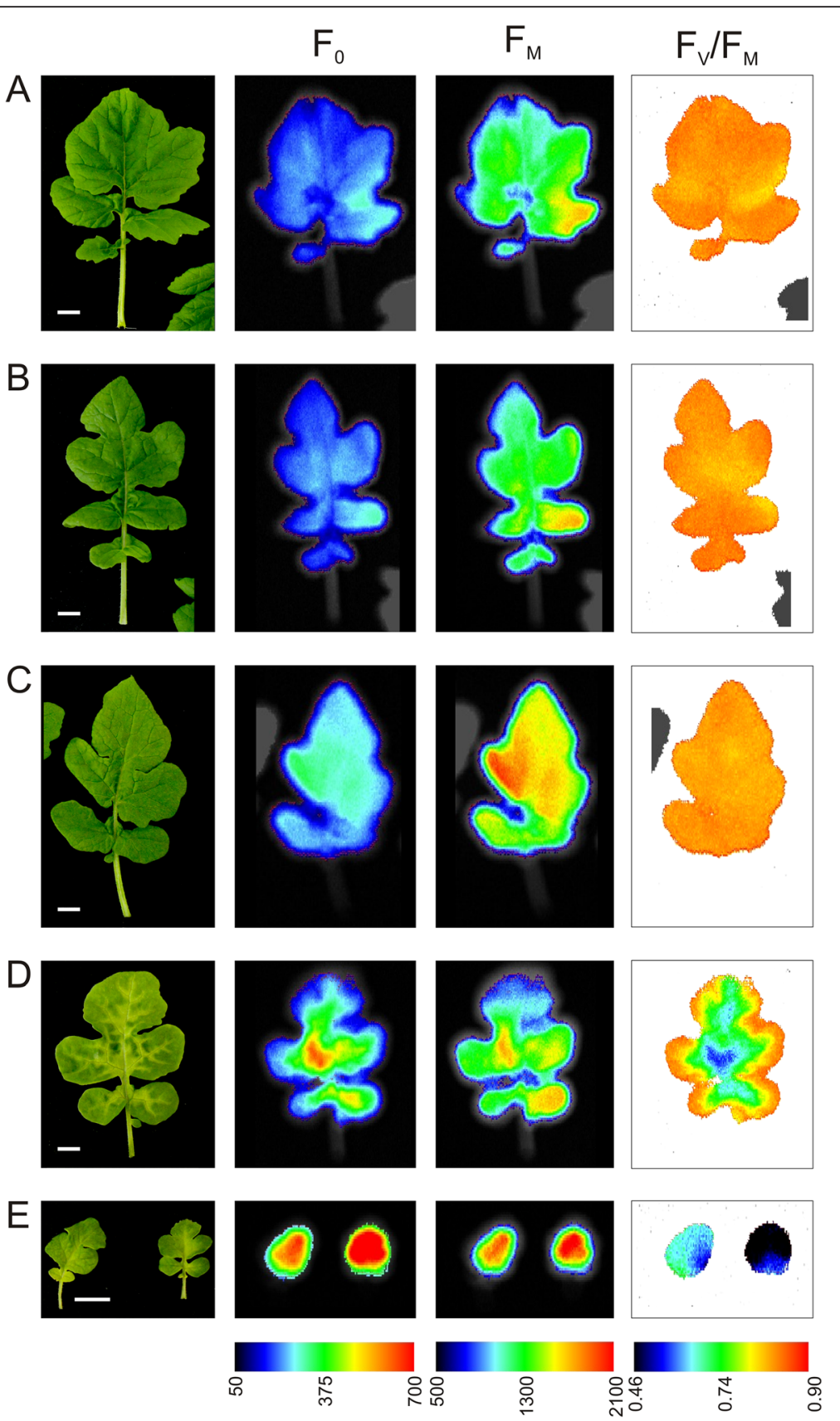

Fig. 4 Chlorophyll a fluorescence imaging of S. alba leaves from control and Tl-treated plants. Pictures present (from left to right): leaf morphology, minimal $\left(F_{0}\right)$ and maximal $\left(F_{M}\right)$ chlorophyll fluorescence distribution and calculated $F_{V} / F_{M}$ value of control (a) and Tl-treated plants $(\mathbf{b}$-e $): 100 \mu g L^{-1}(\mathbf{b})$; $500 \mu \mathrm{g} \mathrm{L}{ }^{-1}$ healthy $(\mathbf{c})$, and affected $(\mathbf{d})$ leaves; $1,000 \mu \mathrm{g} \mathrm{L}(\mathbf{e})$. The images are representative for at least ten leaves from each treatment. Bar $=1 \mathrm{~cm}$

curves averaged over the total leaf area are presented in Additional file 1: Figure S3A. The NPQ parameter for the entire leaf was calculated from these curves and shown in Additional file 1: Figure S3B the NPQ curve has a maximum after the second saturation pulse and later, due to the activation of the photochemical energy dissipation processes resulting in a slow relaxation of $\mathrm{NPQ}$. In leaves with higher concentration of $\mathrm{Tl}$ the NPQ parameter reached higher values and the relaxation was slower. The analysis of the NPQ distribution throughout leaf area (Additional file 1: Figure S3C) showed that in the control, H100, and H500 leaves the kinetics of NPQ was typical for non-stressed plants and correlated well with the $F_{V} / F_{M}$ and leaf surface morphology (Fig. 4). However, in the discolored leaf samples from plants exposed to 500 and $1,000 \mu \mathrm{g} \mathrm{L}^{-1}$ of $\mathrm{Tl}$ the distributions of $\mathrm{NPQ}$ were unequal. At $500 \mu \mathrm{g} \mathrm{L}^{-1}$ the NPQ reached a value above 1.5 in the center of leaf where the most 


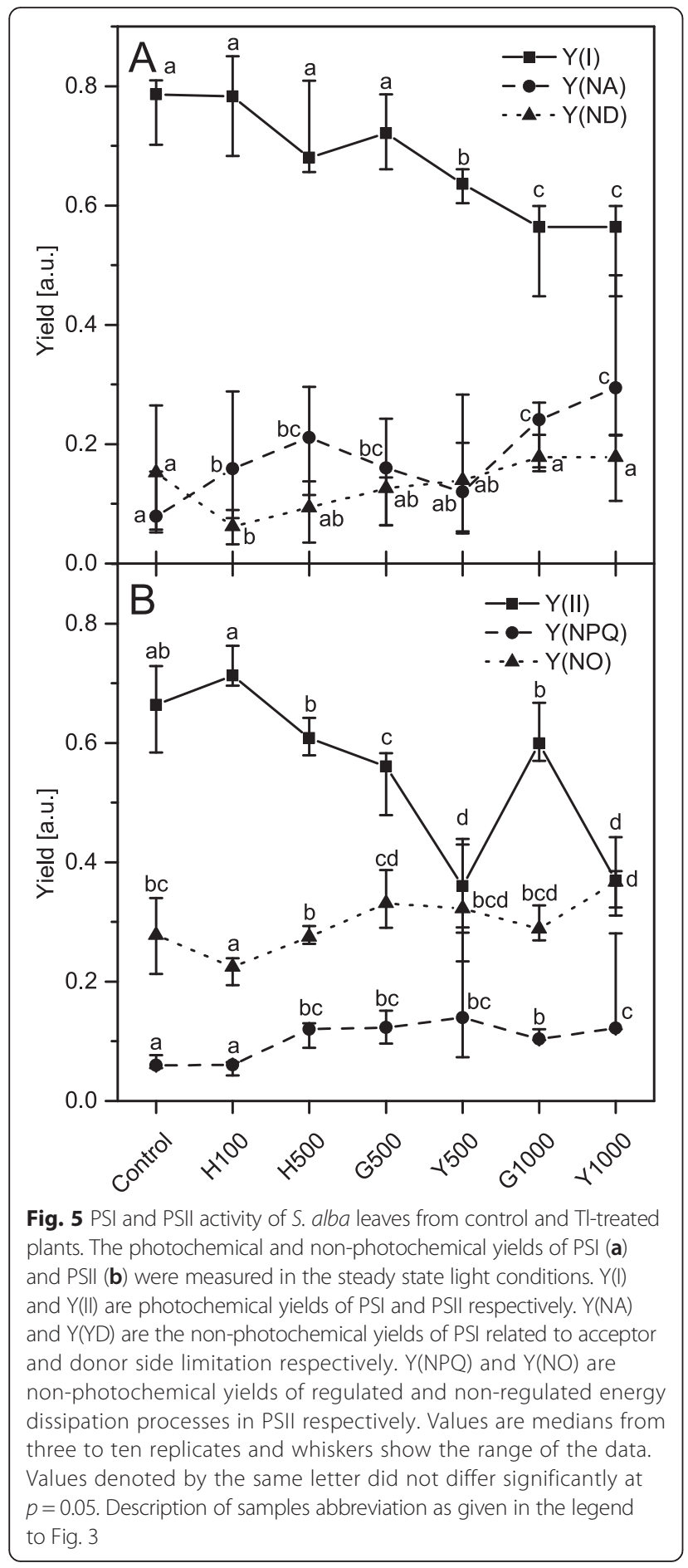

evident discoloration occurred (Fig. 4) and the relaxation of NPQ was much longer compared to control leaves. At $1,000 \mu \mathrm{g} \mathrm{L}^{-1}$ of $\mathrm{Tl}$ the NPQ reached values close to 2.0 and the relaxation during the actinic light illumination was much slower than that in any other examined sample (Additional file 1: Figure S3C).
Quantitative and qualitative analysis of chlorophyll and carotenoid content

It was demonstrated that a diminished chlorophyll (Chl) content and the $\mathrm{Chl} a / b$ ratio under stress conditions indicated degradation of the $\mathrm{Chl}$ molecules together with the decomposition of the CP complexes [7, 57]. In our experiments these parameters (Fig. 6) did not change significantly in green leaves of plants exposed to 100 and $500 \mu \mathrm{g} \mathrm{L}^{-1}$ of $\mathrm{Tl}$, suggesting that the $\mathrm{CP}$ complexes were not damaged under these conditions. In contrast, in the yellow parts of leaves (Y500, Y1000) the total Chl and carotenoid (Car) content decreased by $50 \%$ and $75 \%$, respectively in comparison to the control plants. It should be noted that in G1000 samples this effect was also visible but without statistical significance. Furthermore, the Chl $a / b$ ratio did not change significantly across all plants, while the $\mathrm{Chl} / \mathrm{Car}$ ratio decreased only in the yellowed parts. These observations confirmed that the degradation of the $\mathrm{CP}$ complexes occurred mainly in the yellow parts of leaves while in the green parts the $\mathrm{CP}$ complexes remained structurally intact despite higher $\mathrm{Tl}$ concentration exposure.

The organization of thylakoids and photochemical activity depend on the polar lipid composition, the type of carotenoids associated with the CP complexes [58] and carotenoids directly incorporated into membrane bilayer $[59,60]$ Therefore, determination of carotenoid composition and speciation is important in assessing the physical properties of thylakoids. In the control plant leaves the lutein in the trans conformation reached $56 \%$ of the total carotenoids, while the cis- and trans-neoxanthin, cis- and trans-violaxanthin and cis-lutein were estimated to be $10 \%, 5 \%$ and $5 \%$ of total carotenoids, respectively (Fig. 7). The relative content of other xanthophylls and $\beta$-carotene did not exceed $1 \%$ and $5 \%$, respectively. Traces of zeaxanthin and $\alpha$-carotene were also found.

The exposure of plants to an increasing $\mathrm{Tl}$ concentrations did not significantly affect the molecular forms of neoxanthin (Fig. 7a, b), luteoxanthin (not shown) and antheraxanthin (not shown). The level of the cis-lutein did not differ much from the control, but its level increased in Y1000 samples relative to that in G1000 samples (Fig. 7g). Similar variability was observed for the $\beta$ carotene content, which increased 2-fold in H100 and G100, but at higher $\mathrm{Tl}$ concentration it decreased gradually reaching minimum level in Y1000 samples (Fig. 7c). Nearly linear changes in contents of violaxanthins (Fig. 7d, e) and trans-lutein (Fig. 7f) was also observed. The trans-violaxanthin level, which in control leaves was about $5 \%$, increased to $16 \%$ in Y1000 (Fig. 7d), while trans-lutein decreased to approximately $45 \%$ in both Y500 and Y1000 samples (Fig. 7f). The trans-lutein content in G1000 samples was noticeably higher than those in Y500 and Y1000 samples (Fig. 7f). The analysis of 


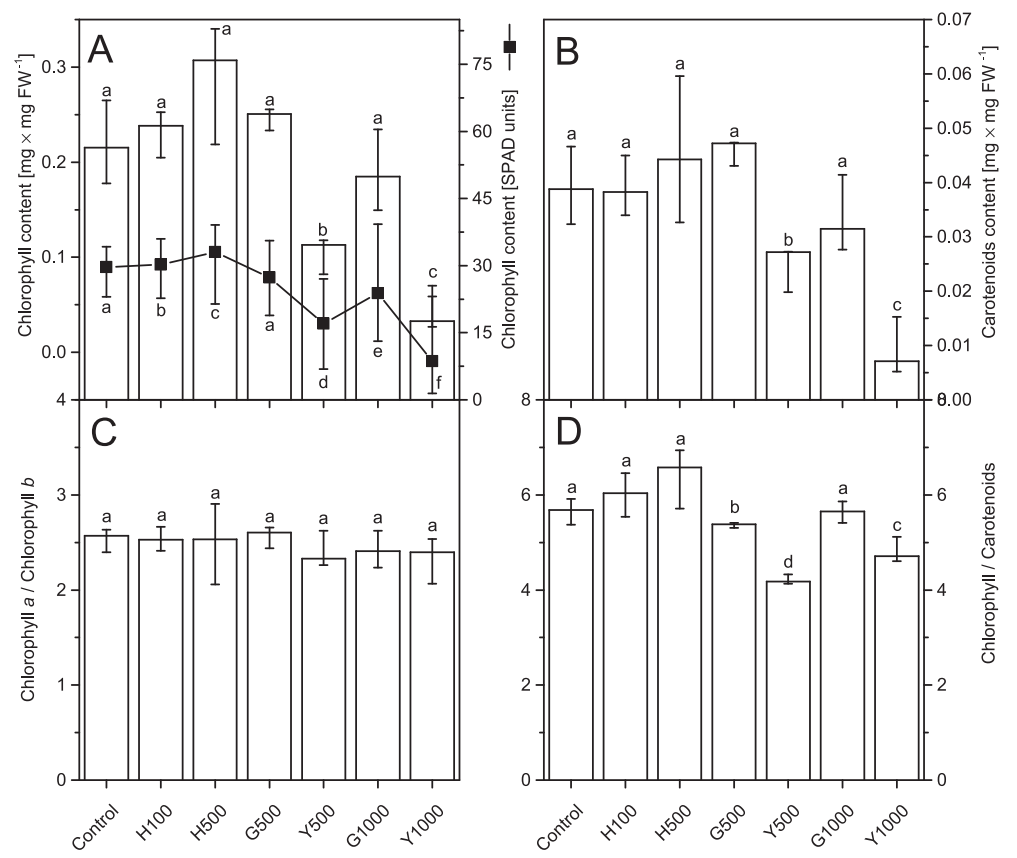

Fig. 6 Chlorophyll and carotenoid content in control and Tl-treated S. alba leaves. Chlorophyll (a) and carotenoid (b) content measured after extraction with acetone and the calculated chlorophyll $a$ to chlorophyll $b$ (c) and chlorophylls to carotenoids (d) ratios. Additionally the chlorophyll concentration (in relative SPAD values) measured directly from the leaf blade (A, black solid line with full squares). Values are medians from three to six replicates and whiskers show the range of the data; in the case of leaf blade measurements there was at least 20 replicates. Values denoted by the same letter did not differ significantly at $p=0.05$. Description of samples abbreviation as given in the legend to Fig. 3

quantitative relationships between different carotenoid species pointed at a significant influence of $\mathrm{Tl}$ on the xanthophylls biosynthesis, in particular on the lutein and neoxanthin pathways.

\section{Analysis of the composition of chlorophyll-protein complexes}

In order to determine the relative contribution of the specific chlorophyll-protein (CP) complexes to the overall fluorescence pattern in thylakoids isolated from plants exposed to different $\mathrm{Tl}$ concentrations, the steady-state fluorescence emission spectra at $77 \mathrm{~K}$ were measured and normalized to the same area (100) under the spectrum (Fig. 8). The control spectrum of white mustard plant thylakoids (Fig. 8a, solid line) exhibited typical features of the fluorescence emission spectrum of higher plants, that is composed of two bands centered at $682 \mathrm{~nm}$ and $729 \mathrm{~nm}$ related to the fluorescence from PSII-LHCII and PSILHCI, respectively. The PSII-LHCII fluorescence band showed a shoulder around $690 \mathrm{~nm}$ which was related to the PSII core complex $[6,61]$.

In Tl-exposed plants the emission spectrum of thylakoids differed from that in the control, with the ratios of the particular bands varied and the band positions shifted (Fig. 8a dashed and dotted lines). For quantitative determination of the observed changes, the difference between the Tl-exposed and control spectra was calculated (Fig. 8b-g). In H100 leaf samples there were no significant changes in the emission spectra (Fig. 8b). The analysis of leaf samples of plants exposed to $500 \mu \mathrm{g} \mathrm{L}^{-1}$ of $\mathrm{Tl}$ (Fig. 8c-e) showed a progressive decrease of the $683 \mathrm{~nm}$ band and an increase of the $733 \mathrm{~nm}$ band, which was also blue-shifted in the Y500 samples (Fig. 8e). Moreover, in the Y500 samples there was a positive band at $676 \mathrm{~nm}$ corresponding to the trimeric LHCII disconnected from PSII [62]. The difference spectra of the G1000 (Fig. 8f) and G500 were very similar but the most pronounced changes were detected in the Y1000 samples (Fig. 8g) where two negative bands at 683 and $733 \mathrm{~nm}$ corresponding to a decrease of PSIILHCII and PSI-LHCI complexes respectively were observed. The positive band at $676 \mathrm{~nm}$ was much higher than that in the corresponding Y500 sample. A wide positive band centered at $703 \mathrm{~nm}$ corresponding to the aggregated form of LHCII antenna complexes [63] was visible. Summarizing, an increased $\mathrm{Tl}$ concentration in leaves appears related to the decrease of the PSII-LHCII and PSI-LHCI supercomplexes and to large increase of the LHCII complexes that are disconnected from the PSII-LHCII, both in the aggregated and trimeric forms.

The analysis of changes in the protein level (Fig. 9) showed that in the Tl-grown plants, especially in yellow parts of the leaves, the levels of PSII core proteins: D1, D2, $\mathrm{CP} 43$ and extrinsic PsbO strongly decreased, which was 

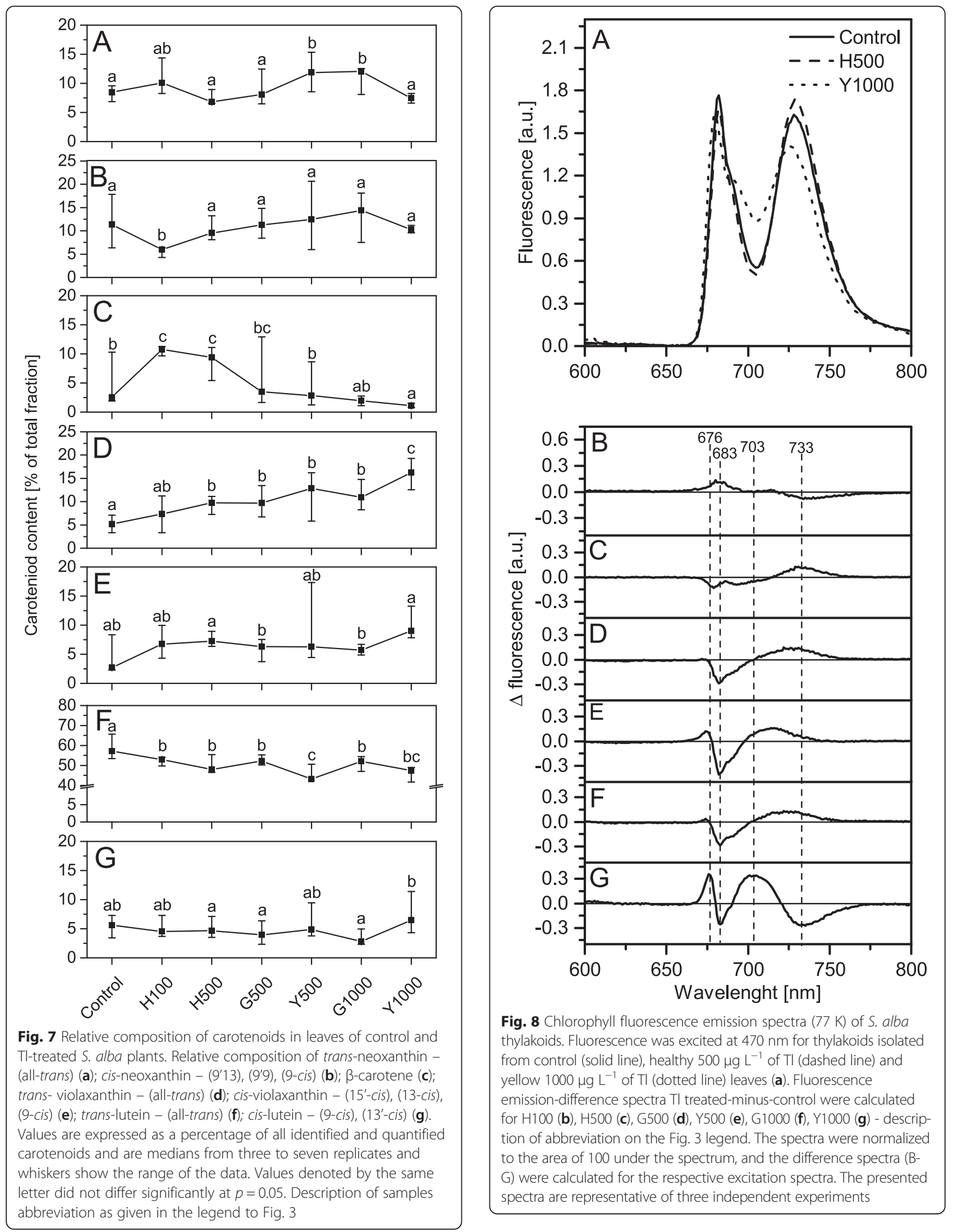


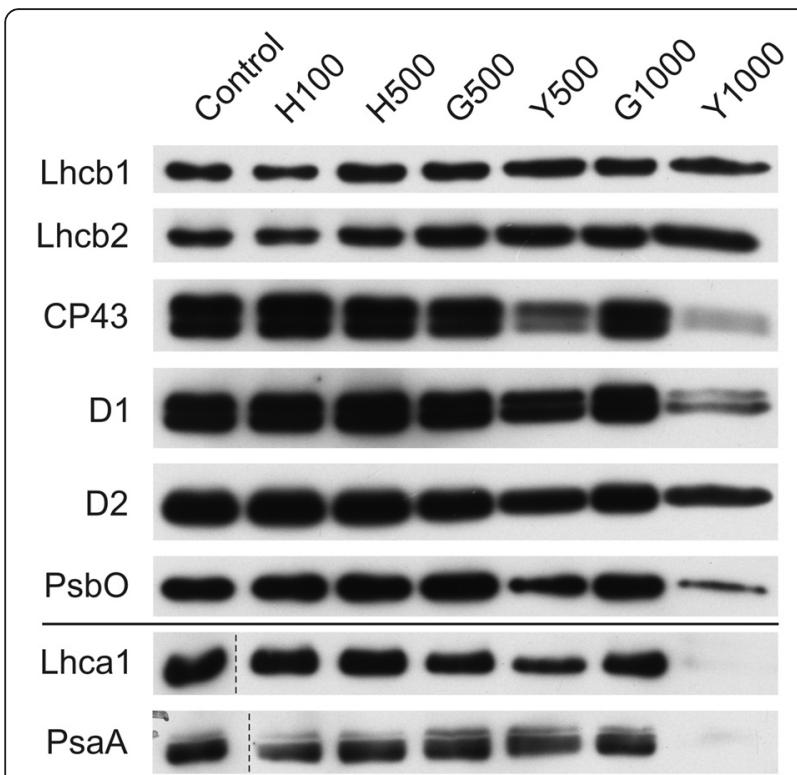

Fig. 9 Changes of PSII and PSI antenna and core protein levels. Proteins from control and Tl-treated white mustard leaves were separated by SDS-PAGE followed by immunodetection with antibodies against Lhcb1, Lhcb2, Lhca1 (antenna proteins) and D1, D2, CP43,

PsbO, PsaA (core proteins). Samples were loaded on the equal amount of chlorophyll $(0.25 \mu \mathrm{g})$. Description of samples abbreviation as given in the legend to Fig. 3

clearly visible in the Y1000 samples. However, the level of antenna proteins Lhcb1 and Lhcb2 - components of the LHCII complex, remained stable. These observations correlated with the $77 \mathrm{~K}$ fluorescence analysis. Additional analysis of the PsaA and Lhca1 proteins - components of the PSI-LHCI supercomplex showed that both antenna (Lhca1) and core (PsaA) protein levels decreased in the Y500 and Y1000 samples in comparison to the controls and in Y1000 they reached undetectable level.

\section{Discussion}

The effect of an increasing dose of $\mathrm{Tl}$ on the functional and structural basis of photosynthesis was investigated in this study by many complementary methods. The results allowed to distinguish between different features of $\mathrm{Tl}$ toxicity. The overall effect was visible as a decrease in the root tolerance index (Fig. 1), the plant and leaf size, the number of discolored and necrotic leaves (Additional file 1: Figure S1), changes in the mesophyll structure (Additional file 1: Figure S2) and a $50 \%$ decline in the PSI (Y(I)) and PSII (Y(II)) photochemical activities (Fig. 5).

Increased $\mathrm{Tl}$ concentration in culture media gradually affected root development and growth. The most characteristic macroscopic change of this effect was a reduction of the root length at highest concentration of the toxicant. However, the tolerance index of plants grown in the lowest applied concentration changed significantly during the experiment - it increased up to the level of control along with the 2-fold decrease of $\mathrm{Tl}$ concentration in the medium. Thus, plants were exposed to a decreasing concentration of $\mathrm{Tl}$ during the cultivation. This could explain high tolerance of $S$. alba to $100 \mu \mathrm{g} \mathrm{L}^{-1}$ at the end of treatment. For plants treated with $500 \mu \mathrm{g} \mathrm{L}^{-1}$ of $\mathrm{Tl}$, an increase of root tolerance index was also noticed, as well as a decrease of $\mathrm{Tl}$ concentration in the medium; however, the concentration of $\mathrm{Tl}$ that affected plants during the experiment was still much higher than $100 \mu \mathrm{g} \mathrm{L}{ }^{-1}$. Therefore, the tolerance index of plants treated with $500 \mu \mathrm{g} \mathrm{L}{ }^{-1}$ of $\mathrm{Tl}$ in the initial concentration was significantly lower in comparison with plants exposed to $100 \mu \mathrm{g} \mathrm{L}^{-1}$ of $\mathrm{Tl}$ at the end of treatment. We assumed that plants exposed to concentration of $500 \mu \mathrm{g} \mathrm{L}^{-1}$ of $\mathrm{Tl}$ at the beginning of experiment were moderately affected by toxic effects of thallium. Thus, two types of changes in leaves of these plants were observed. The exposure to $1,000 \mu \mathrm{g} \mathrm{L}^{-1}$ of $\mathrm{Tl}$ caused severe effects of toxicity for the whole plant. Root growth was strongly inhibited resulting in a complex reaction of plants by combination of various disturbances, being secondary effects of $\mathrm{Tl}$ action (disturbance of water balance, ion homeostasis, and oxidative stress). Therefore, inhibition of photosynthesis in plants exposed to $1,000 \mu \mathrm{g} \mathrm{L}^{-1}$ of $\mathrm{Tl}$ was caused by indirect effects of high $\mathrm{Tl}$ concentration. Summing up, a gradual effect on the photosynthetic parameters in $S$. alba exposed to increasing concentrations of $\mathrm{Tl}$ was due to the transition from lack of toxicity symptoms at $100 \mu \mathrm{g} \mathrm{L}^{-1}$, through moderate toxicity and increasing sensitivity of plants treated with $500 \mu \mathrm{g} \mathrm{L}^{-1}$, to high toxicity and breakdown of the whole plant homeostasis by $1,000 \mu \mathrm{g} \mathrm{L} \mathrm{L}^{-1}$.

Thallium moves freely across cell membranes and accumulates in cells $[24,64]$ due to similarity of $\mathrm{Tl}^{+}$and $\mathrm{K}$ ${ }^{+}$ions. The $S$. alba roots accumulate the lowest amounts of $\mathrm{Tl}$ because it is effectively transported into the aboveground organs. Considering the biomass, $80 \%$ of the up taken $\mathrm{Tl}$ was found in leaves and stems [65]. These data suggest that the leaf cells and the photosynthetic process are important targets of $\mathrm{Tl}$ toxicity. This is not different from the action of other heavy metals, which affect directly or indirectly the photosynthetic reactions (see references in Introduction).

Visible signs of excessive heavy metals exposure is chlorosis preceding the necrosis of leaf tissues, advancement of which depends on susceptibility of plant species and metal concentration [66]. The damaged cells are usually clustered in discolored or necrotic spots randomly arranged in the leaf blade in plants treated with $\mathrm{Cu}, \mathrm{Cd}$ or $\mathrm{Zn}$ among others [12, 66-68]. Thalliuminduced changes in morphology and photochemical activity gradually spread around the main vascular bundles of leaves (Fig. 4). This effect was most clearly visible in leaves from plants exposed to $500 \mu \mathrm{g} \mathrm{L}^{-1}$ of $\mathrm{Tl}$ (Fig. 4d), where the overall moderate toxicity (Fig. 1) was analyzed 
in three selected leaf areas. The concentration of $\mathrm{Tl}$ in Y500 was twice as high as in H500 and G500 samples. Noticeable concentration of $\mathrm{Tl}(\mathrm{III})$ was detected in H500 and G500 leaves (Fig. 2), despite the fact that the nutrient solutions contained $\mathrm{Tl}(\mathrm{I})$ only. Oxidation of $\mathrm{Tl}(\mathrm{I})$ took place in plant tissue and the content of $\mathrm{Tl}(\mathrm{III})$ reached up to $10 \%$ of total $\mathrm{Tl}$, as we showed in our previous study on mustard plants grown in spiked soil [69]. In comparison to $\mathrm{Tl}(\mathrm{III})$ the monovalent thallium is thermodynamically more stable and less reactive which makes it the dominant form of $\mathrm{Tl}$. In contrast to $\mathrm{Tl}(\mathrm{I})$ the trivalent thallium forms very stable complexes with many ligands thus resulting with reduced toxicity [70].

As was establish in model systems and in animal cells the reactions of $\mathrm{Tl}(\mathrm{I})$ with reduced compounds produce $\mathrm{Tl}(0)$ and organic free radicals [71]. In plant cells these reactions might proceed by direct interactions with reduced components of the photosynthetic chain. $\mathrm{Tl}(0)$ and organic radicals subsequently react with the molecular oxygen producing superoxide $\left(\mathrm{O}_{2}^{-*}\right)$, which is later dismutased to other reactive oxygen species (ROS) both by enzymatic and autocatalytic reactions [71]. ROS initiate the peroxidative chain reactions $[40,72,73]$, among others they react with $\mathrm{Tl}(\mathrm{I})$ producing thallic ions $\mathrm{Tl}(\mathrm{III})$, a dangerous strong oxidant $\left(\mathrm{E}_{0} \mathrm{Tl}^{3+} / \mathrm{Tl}^{+}=1.2 \mathrm{~V}\right) . \mathrm{Tl}(\mathrm{III})$ can initiate the lipid or protein peroxidation and cause regeneration of the more reduced $\mathrm{Tl}(\mathrm{I})$, which can react again with ROS $[72,74]$. This hypothetical Tl-ROS cycle takes place most likely in chloroplasts in thylakoid membranes, but further studies are required for elucidation of the molecular mechanism.

Accumulation of $\mathrm{Tl}(\mathrm{III})$ was only observed in $\mathrm{H} 500$ and G500 samples (Fig. 2) and in these samples the photochemical yield $\mathrm{Y}(\mathrm{I})$ and $\mathrm{Y}(\mathrm{II})$ decreased by $20 \%$ of the control levels (Fig. 5) without changes in the maximal quantum yield of PSII $\left(\mathrm{F}_{\mathrm{V}} / \mathrm{F}_{\mathrm{M}}\right)$ (Fig. 4). The chlorophyll and carotenoid contents (Fig. 6) as well as arrangement of the thylakoid membranes (Fig. 3) remained unchanged and in G1000 samples these parameters resembled those observed in H500 and G500 samples.

The maximal quantum yield $\left(\mathrm{F}_{\mathrm{V}} / \mathrm{F}_{\mathrm{M}}\right)$ is related to open reaction centers and decreases in impaired PSII complexes [75-77], whereas the $\mathrm{Y}(\mathrm{I})$ and $\mathrm{Y}(\mathrm{II})$ depend not only on the connection between reaction centers but also on the amount of down-regulation processes [78]. Simultaneously with the decrease of the photochemical activity in the H500 and G500 samples an increase of the non-photochemical parameters was observed (Fig. 5), which indicates a limitation in the oxidation (PSI) and reduction (PSI, PSII) of photosystems [78]. Therefore we suggest that thallium influences the photosynthesis without degradation of the CP complexes and grana structure in the H500, G500 and partly in G1000 samples. Noticeably the percentage level of $\mathrm{Tl}(\mathrm{III})$ in the total amount of thallium suggests that the Tl-ROS cycle is restricted probably by antioxidant systems and only a direct interaction of $\mathrm{Tl}(\mathrm{I})$ with reduced electron carriers of the photosynthetic chain occurs. Furthermore, in H500 samples the increase of both $F_{0}$ and $F_{M}$ values due to a significant increase of chlorophyll concentration (Figs. 4 and 6) can be interpreted as an attempt to acclimatization of plants to a higher $\mathrm{Tl}$ concentration.

The analysis of the protein composition of the main thylakoids complexes in H500, G500 and even in G1000 samples (Fig. 9) did not show changes in protein levels nor in the ratios of core and antennae proteins. These data taken together with a stable value of the maximal quantum yield of PSII (Fig. 4) suggested the integrity of the $\mathrm{CP}$ complexes was not affected. However, low-temperature fluorescence spectra (Fig. 8) indicated a decrease in the connectivity between the external antennae and core complexes of PSII with a simultaneous increase of the PSI fluorescence intensity. This observation can be related to a certain energy spillover from PSII to PSI $[79,80]$. The basic unit of LHCII-PSII consists of dimeric form of PSII, two copies of monomeric antennae and two LHCII trimers. Moreover, up to four other LHCII trimers might be weakly associated with PSII dimer [5, 81]. The LHCI-PSI complex in unstacked regions of membranes might bound the LHCII trimer, creating a new supercomplex [82]. It appears probable that in H500, G500 and G1000 samples the part of loosely associated LHCII trimers is bound to the LHCI-PSI complexes without visible changes in the grana structure (Fig. 3). Despite that in H500 and G500 samples the overall carotenoid levels did not decrease (Fig. 6), noticeable qualitative changes of the carotenoid species were observed (Fig. 7). Variations of the relative amount of violaxanthin, lutein and carotene might modulate the membrane rigidity and support the protein diffusion $[59,83]$.

Thus, we have shown that the first non-destructive stage of the thallium toxicity is associated with two overlapping effects: $(i)$ direct influence of $\mathrm{Tl}$ on photochemistry and (ii) partial rearrangements of the CP complexes. Furthermore, the early phase of toxicity in young H500 leaves was associated with an active response to the Tl stress by an increase of the chlorophyll and carotene concentration (Figs. 6 and 7).

The next stage of thallium toxicity, probably more closely related to an indirect toxic effect (Fig. 1), revealed by the simultaneous functional disorder of PSI and PSII photochemistry (Fig. 5) and the PSII quantum yield (Fig. 4), appears associated with the CP complexes degradation [84]. In Y500 and Y1000 samples a substantial decrease of the chlorophyll and carotenoid levels (Fig. 6) was associated with a 2- and 3-fold increase of $\mathrm{Tl}(\mathrm{I})$ concentration, respectively, but thallium oxidation to $\mathrm{Tl}$ (III) was not observed (Fig. 2). This might suggest 
an increase of the Tl-ROS cycle rate and insufficient activity of the antioxidant systems, which may lead to oxidation of the thylakoids pigments [40]. Large deficiency of the $\beta$-carotene in Y1000 samples (Fig. 7c) appears indicative of these processes.

Since $F_{0}$ originated from the chlorophylls associated with antennae complexes almost triple increase of $F_{0}$ fluorescence in Y500 and Y1000 samples (Fig. 4) indicated a decreased energy transfer from the LHCII to PSII cores due to disconnection of the antennae from LHCII-PSII $[75,78]$. Furthermore, the appearance of 676 and $700 \mathrm{~nm}$ bands in the $77 \mathrm{~K}$ difference spectra (Fig. 8e, g) attributed to the emission from the trimeric or aggregated form of the LHCII non-associated with PSII reaction centers $[6,52,62,79]$ confirmed that the increase of $F_{0}$ is related to disintegration of the LHCII-PSII supercomplexes [75]. Moreover, higher values and slow relaxation of the NPQ parameter (Additional file 1: Figure S3) observed in Y500 and Y1000 leaves is usually related to the aggregation of LHCII $[85,86]$. A noticeable decrease in the relative amount of the PSII core proteins (D1, D2, CP43) without significant changes in the level of the LHCII proteins (Lhcb1, Lhcb2) lead to an increase of the antennae/core protein ratio (Fig. 9) and suggests rearrangements or a partial decline of the LHCII-PSII supercomplexes. A significant decrease in the PsbO protein level (Fig. 9) may cause dissociation of the Mn-cluster, inhibition of the oxygen evolution and a decrease of the PSII quantum yield (Fig. 4) [11, 75]. It is worth noticing that the levels of the core (PsaA) and antennae (Lhca1) proteins of the LHCI-PSI complex were stable in all samples but were absent in the Y1000 parts of leaves (Fig. 9). The LHCII protein levels in Y500 and Y1000 samples were the same as in the other part of leaves, while the level of the core proteins of PSII was lower but these proteins were still present (Fig. 7). The structure of grana stacks is mainly stabilized by an ordered arrangement of the LHCII-PSII and LHCII complexes [5], while the unstacking of grana is related to the disconnection of LHCII from supercomplexes and random distribution of the photosystems in the lateral plane of the thylakoid membrane [79]. Therefore, we propose that the decrease in the content and disordered arrangements of supercomplexes, mainly LHCII-PSII, were responsible for the decline of the grana structure observed in Y500 and Y1000 samples (Fig. 3).

\section{Conclusions}

In this study we have identified two phases of thallium toxicity. In the first phase a direct influence of thallium on the photochemistry reactions and partial rearrangements of the photosynthetic complexes was observed without significant changes in the pigment and protein levels, and in the chloroplast structure. The second phase, probably indirect destructive phase of thallium toxicity that was observed in the discolored leaf areas only, is associated with massive oxidation of pigments, decrease of the photosynthetic core protein levels, disorder of the $\mathrm{CP}$ complexes and grana disappearance. The border between the first (non-destructive) and second (destructive) phase of thallium toxicity is not very distinct as the two phases overlapped. The intensity of thallium toxicity is proportional to the $\mathrm{Tl}$ migration outside the vascular bundles, its accumulation in tissues, and time of action. The toxicity seems to be related to the ratio between the two observed chemical forms of thallium: $\mathrm{Tl}(\mathrm{I})$ and $\mathrm{Tl}(\mathrm{III})$.

\section{Additional file}

Additional file 1: Figure S1. Morphology of white mustard plants grown in the control conditions (A) and in the presence of thallium in concentration $100 \mu \mathrm{g} \mathrm{L} \mathrm{L}^{-1}$ (B), $500 \mu \mathrm{gL}^{-1}$ (C) and 1,000 $\mathrm{gg} \mathrm{L}^{-1}$ (D). Bar $=2.5 \mathrm{~cm}$. Figure S2. Changes of leaf blade architecture of white mustard plants grown in the presence of thallium revealed by bright field microscopy. Pictures show leaf blade cross-sections from control (A) and Tl-treated plants (B-G): $100 \mu \mathrm{g} \mathrm{L}^{-1}$ (H100) (B); $500 \mu \mathrm{g} \mathrm{L}{ }^{-1}$ healthy green leaves, which showed no changes in morphology comparing to the control cultivation (H500) (C), green (G500) (D) and yellow (Y500) (E) parts of the affected leaves; 1,000 $\mathrm{Mg} \mathrm{L}^{-1}$ green (G1000) (F) and yellow (Y1000) (G) parts of the affected leaves. Figure S3. Analysis of non-photochemical quenching parameter (NPQ) in the dark adapted white mustard leaves from control and Tl-treated plants presented on Fig. 3. (A) an exemplary fluorescence traces for control, $500 \mu \mathrm{g} \mathrm{L}^{-1}$ of $\mathrm{Tl}$ and $1,000 \mu \mathrm{g} \mathrm{L}^{-1}$ of $\mathrm{Tl}$ leaves recorded during exposition of dark-adapted leaves to actinic light illumination. (B) Changes of NPQ parameter calculated for the entire leaf area on the basis of recorded fluorescence traces during actinic light illumination. (C) Visualization of the induction and relaxation of NPQ throughout the leaf. The images are representative for at least ten leaves from each treatment. Description of samples abbreviation as given in the legend to Fig. 3. (PDF 629 kb)

\section{Acknowledgements}

This work was carried out with the use of CePT infrastructure financed by the European Union - the European Regional Development Fund within the Operational Programme "Innovative economy" for 2007-2013. TEM images were performed in the Laboratory of Electron Microscopy, Nencki Institute of Experimental Biology on JEM 1400 (JEOL Co. Japan) electron microscope. This equipment was installed within the project sponsored by the EU Structural Funds: Centre of Advanced Technology BIM - Equipment purchase for the Laboratory of Biological and Medical Imaging. We thank Dr Wojtek P. Michalski for critical reading of the manuscript.

\section{Funding}

This work was supported by National Science Centre (NCN), Poland [grant number DEC-2011/01/B/NZ8/00052].

\section{Availability of data and materials}

The datasets during and/or analyzed during the current study available from the corresponding author on reasonable request.

\section{Authors' contributions}

RM and MS contributed equally to this work. RM, MS, MG, BK-O designed the experiments. RM, MS, ŁK, AA, HMK, MG performed the experiments and RM, $M S, \ell K, A A, M G, A M, B K-O$ analyzed the data. RM, MG, MS, AM, AA wrote the manuscript. All authors read and approved the final manuscript.

\section{Competing interests}

The authors declare that they have no competing interests.

Consent for publication

Not applicable. 


\section{Ethics approval and consent to participate}

Not applicable.

\begin{abstract}
Author details
${ }^{1}$ Department of Metabolic Regulation, Faculty of Biology, University of Warsaw, Miecznikowa 1, 02-096 Warsaw, Poland. ' Laboratory of Chromatography and Environmental Analysis, Faculty of Chemistry, University of Warsaw, Pasteura 1, 02-093 Warsaw, Poland. ${ }^{3}$ Department of Plant Anatomy and Cytology, Faculty of Biology, University of Warsaw, Miecznikowa 1, 02-096 Warsaw, Poland. ${ }^{4}$ Laboratory of Ecotoxicology, Institute of Botany, Faculty of Biology, University of Warsaw, Miecznikowa 1, 02-096 Warsaw, Poland. ${ }^{5}$ Department of Plant Physiology, Warsaw University of Life Sciences SGGW, Nowoursynowska 159, 02-776 Warsaw, Poland.
\end{abstract}

\section{Received: 5 July 2016 Accepted: 25 August 2016}

Published online: 02 September 2016

\section{References}

1. Mustardy L, Buttle K, Steinbach G, Garab G. The three-dimensional network of the thylakoid membranes in plants: quasihelical model of the granumstroma assembly. Plant Cell. 2008;20(10):2552-7.

2. Austin 2nd JR, Staehelin LA. Three-dimensional architecture of grana and stroma thylakoids of higher plants as determined by electron tomography Plant Physiol. 2011;155(4):1601-11.

3. Daum B, Kuhlbrandt W. Electron tomography of plant thylakoid membranes. J Exp Bot. 2011;62(7):2393-402.

4. Dekker JP, Boekema EJ. Supramolecular organization of thylakoid membrane proteins in green plants. Biochim Biophys Acta. 2005;1706(1-2):12-39.

5. Kouril R, Dekker JP, Boekema EJ. Supramolecular organization of photosystem II in green plants. Biochim Biophys Acta. 2012;1817(1):2-12.

6. Rumak I, Mazur R, Gieczewska K, Kozioł-Lipińska J, Kierdaszuk B, Michalski WP, Shiell BJ, Venema JH, Vredenberg WJ, Mostowska A, et al. Correlation between spatial (3D) structure of pea and bean thylakoid membranes and arrangement of chlorophyll-protein complexes. BMC Plant Biol. 2012;12(1):72.

7. Maksymiec W. Signaling responses in plants to heavy metal stress. Acta Physiologiae Plantarum. 2007;29(3):177-87.

8. Parmar P, Kumari N, Sharma V. Structural and functional alterations in photosynthetic apparatus of plants under cadmium stress. Botanical Studies. 2013;54(1):45.

9. Myśliwa-Kurdziel MNV, Prasad KS. Heavy metal influence on the light phase of photosynthesis. In: PMNVaS K, editor. Physiology and biochemistry of metal toxicity and tolerance in plants. Dordrecht: Kluwer Academic Press; 2002. p. 229-55.

10. Kalaji HM, Loboda T. Photosystem II of barley seedlings under cadmium and lead stress. Plant, Soil and Environment. 2007;53(12):511-6.

11. Mishra S, Dubey RS. Heavy metal toxicity induced alterations in photosynthetic metabolism in plants. In: Pessarakli M, editor. Handbook of Photosynthesis. Secondth ed. Boca Raton: CRC Press; 2005. p. 845-63.

12. Peng $\mathrm{H}$, Kroneck PM, Kupper $\mathrm{H}$. Toxicity and deficiency of copper in Elsholtzia splendens affect photosynthesis biophysics, pigments and metal accumulation. Environ Sci Technol. 2013;47(12):6120-8.

13. Janik E, Maksymiec W, Mazur R, Garstka M, Gruszecki WI. Structural and functional modifications of the major light-harvesting complex II in cadmiumor copper-treated Secale cereale. Plant and Cell Physiology. 2010;51 (8):1330-40.

14. Sarvari E. Effect of heavy metals on chlorophyll-protein complexes in higher plants: causes and consequences. In: Pessarakli M, editor. Handbook of Photosynthesis. Secondth ed. Boca Raton: CRC Press; 2005. p. 845-63.

15. D'Alessandro A, Taamalli M, Gevi F, Timperio AM, Zolla L, Ghnaya T. Cadmium stress responses in Brassica juncea: hints from proteomics and metabolomics. J Proteome Res. 2013;12(11):4979-97.

16. Krasnodębska-Ostręga B, Dmowski K, Stryjewska E, Golimowski J. Determination of Thallium and Other Elements ( $\mathrm{As}, \mathrm{Cd}, \mathrm{Cu}, \mathrm{Mn}, \mathrm{Pb}, \mathrm{Se}, \mathrm{Sb}$, and $\mathrm{Zn}$ ) in Water and Sediment Samples from the Vicinity of the Zinc-Lead Smelter in Poland (3 pp). J Soils and Sediments. 2005:5(2):71-3.

17. Pošćić F, Fellet G, Vischi M, Casolo V, Schat H, Marchiol L. Variation in heavy metal accumulation and genetic diversity at a regional scale among metallicolous and non-metallicolous populations of the facultative metallophyte biscutella laevigata subsp. laevigata. Int J Phytoremediation. 2015;17(1-6):464-75.

18. Fellet G, Pošćić F, Casolo V, Marchiol L. Metallophytes and thallium hyperaccumulation at the former Raibl lead/zinc mining site (Julian Alps, Italy). Plant Biosystems. 2012;146(4):1023-36.
19. Marques M, Martinez-Conde E, Rovira J, Ordonez S. Heavy metals pollution of aquatic ecosystems in the vicinity of a recently closed underground leadzinc mine (Basque Country, Spain). Environ Geol. 2001;40:1125-37.

20. Sasmaz A, Sen O, Kaya G, Yaman M, Sagiroglu A. Distribution of thallium in soil and plants growing in the keban mining district of turkey and determined by ICP-MS, vol. 28. Shelton: Perkin Elmer; 2007.

21. Queirolo F, Stegen S, Queirolo A, Contreras-Ortega C, Paredes B. Thallium levels and bioaccumulation in environmental samples of northern Chile: human health risks. J Chilean Chem Soc. 2009;54(4):464-9.

22. Zhang G, Liu C-Q, Yang Y, Wu P. Characterization of heavy metals and sulphur isotope in water and sediments of a mine-tailing area rich in carbonate. Water Air Soil Pollut. 2004;155(1-4):51-62.

23. Keith $L H$, Telliard WA. Priority pollutants: I. A perspective view. Environ Sci Tech. 1979;13(4):416-23.

24. Nriagu JO. "Thallium in the Environment", series: Advances in Environmental Science and Technology. New York: Wiley \& Sons:; 1998.

25. Wierzbicka M, Szarek-Łukaszewska G, Grodzińska K. Highly toxic thallium in plants from the vicinity of Olkusz (Poland). Ecotoxicol Environ Saf. 2004;59(1):84-8.

26. Dmowski K, Badurek M: Thallium contamination of selected plants and fungi in the vicinity of the Boleslaw Zinc Smelter in Bukowno [S.Poland]. Preliminary study. Acta Biologica Cracoviensia Series Botanica. 2002;44:57-61.

27. Escarré J, Lefèbvre C, Raboyeau S, Dossantos A, Gruber W, Cleyet Marel JC, Frérot H, Noret N, Mahieu S, Collin C, et al. Heavy Metal Concentration Survey in Soils and Plants of the Les Malines Mining District (Southern France): Implications for Soil Restoration. Water, Air, Soil Pollut. 2010;216(1):485-504.

28. Scheckel KG, Lombi E, Rock SA, McLaughlin MJ. In vivo synchrotron study of thallium speciation and compartmentation in Iberis intermedia. Environ Sci Technol. 2004;38(19):5095-100

29. LaCoste C, Robinson B, Brooks R, Anderson C, Chiarucci A, Leblanc M. The Phytoremediation Potential of Thallium-Contaminated Soils Using Iberis and Biscutella Species. Int J Phytoremediation. 1999;1 (4):327-38.

30. Leblanc M, Petit D, Deram A, Robinson BH, Brooks RR. The phytomining and environmental significance of hyperaccumulation of thallium by lberis intermedia from southern France. Econ Geol. 1999;94(1):109-13.

31. Anderson CWN, Brooks RR, Chiarucci A, LaCoste CJ, Leblanc M, Robinson BH, Simcock R, Stewart RB. Phytomining for nickel, thallium and gold. J Geochem Explor. 1999;67(1-3):407-15.

32. Pošćić F, Marchiol L, Schat H. Hyperaccumulation of thallium is populationspecific and uncorrelated with caesium accumulation in the thallium hyperaccumulator, Biscutella laevigata. Plant and Soil. 2012;365(1):81-91.

33. Krasnodębska-Ostręga B, Piekarska J. Determination of Lead and Cadmium at Silver Electrode by Subtractive Anodic Stripping Voltammetry in Plant Materials Containing TI. Electroanalysis. 2005;17(9):815-8.

34. Vanek A, Komarek M, Chrastny V, Becka D, Mihaljevic M, Sebek O, Panuskova G, Schusterova Z. Thallium uptake by white mustard (Sinapis alba L.) grown on moderately contaminated soils-agro-environmental implications. J Hazard Mater. 2010;182(1-3):303-8.

35. Krasnodębska-Ostręga B, Asztemborska M, Golimowski J, Strusińska K. Determination of thallium forms in plant extracts by anion exchange chromatography with inductively coupled plasma mass spectrometry detection (IC-ICP-MS). J Analytical Atomic Spectrometry. 2008;23(12):1632.

36. Tremel A, Masson P, Garraud H, Donard OFX, Baize D, Mench M. Thallium in French agrosystems- - II. Concentration of thallium in field-grown rape and some other plant species. Environ Pollut. 1997;97(1-2):161-8.

37. Kurz $H$, Schulz R, Römheld V. Selection of cultivars to reduce the concentration of cadmium and thallium in food and fodder plants. J Plant Nutrition and Soil Sci. 1999;162(3):323-8.

38. Van der Ent A, Baker AJM, Reeves RD, Pollard AJ, Schat H. Hyperaccumulators of metal and metalloid trace elements: Facts and fiction. Plant and Soil. 2012;362(1):319-34.

39. Nolan A, Schaumlöffel D, Lombi E, Ouerdane L, Łobiński R, McLaughlin M. Determination of TI(I) and TI(III) by IC-ICP-MS and application to TI speciation analysis in the TI hyperaccumulator plant Iberis intermedia. J Analytical Atomic Spectrometry. 2004;19(6):757.

40. Radić S, Cvjetko P, Glavas K, Roje V, Pevalek-Kozlina B, Pavlica M. Oxidative stress and DNA damage in broad bean (Vicia faba L.) seedlings induced by thallium. Environ Toxicol Chem. 2009;28(1):189-96.

41. Aoki M, Matsumoto H, Takahashi T, Sato K, Kumata H, Fujiwara K. Thallium Induces morphological changes in the photosynthetic apparatus of Synechocystis sp. PCC6803. In: Kuang T, Lu C, Zhang L, editors. Photosynthesis Research for Food, Fuel and the Future. Berlin Heidelberg: Springer; 2013. p. 586-9. 
42. Aoki M, Suematsu H, Kumata H, Fujiwara K. Physiological and Photosynthetic ToxiCity of Thallium in Synechocystis sp. PCC6803. In: Allen J, Gantt E, Golbeck J, Osmond B, editors. Photosynthesis Energy from the Sun. Dordrecht: Springer; 2008. p. 1399-402.

43. Wilkins DA. The measurement of tolerance to edaphic factors by means of root growth. New Phytologist. 1978;80(3):623-33.

44. Wilkins DA. A Technique for the Measurement of Lead Tolerance in Plants. Nature. 1957;180(4575):37-8.

45. Genty B, Briantais J-M, Baker NR. The relationship between the quantum yield of photosynthetic electron transport and quenching of chlorophyll fluorescence. Biochim Biophys Acta Gen Subj. 1989;990(1):87-92.

46. Kramer DM, Johnson G, Kiirats O, Edwards GE. New fluorescence parameters for the determination of $\mathrm{q}(\mathrm{a})$ redox state and excitation energy fluxes. Photosynth Res. 2004;79(2):209-18.

47. Klughammer C, Schreiber U. Saturation Pulse method for assessment of energy conversion in PS I. PAM Application Notes. 2008;1:11-4.

48. Lakowicz J. Principles of Fluorescence Spectroscopy. New York: Springer; 2010.

49. Lichtenthaler $\mathrm{H}$. Chlorophylls and carotenoids-pigments of photosynthetic biomembranes. Methods Enzymol. 1987;148:350-82.

50. Szalonek M, Sierpien B, Rymaszewski W, Gieczewska K, Garstka M, Lichocka M, Sass L, Paul K, Vass I, Vankova R, et al. Potato Annexin STANN1 Promotes Drought Tolerance and Mitigates Light Stress in Transgenic Solanum tuberosum L. Plants PLoS One. 2015;10(7), e0132683.

51. Sztaray J, Memboeuf A, Drahos L, Vekey K. Leucine enkephalin-a mass spectrometry standard. Mass Spectrom Rev. 2010;30(2):298-320.

52. Janik E, Bednarska J, Zubik M, Puzio M, Luchowski R, Grudzinski W, Mazur R, Garstka M, Maksymiec W, Kulik A, et al. Molecular architecture of plant thylakoids under physiological and light stress conditions: a study of lipid-lightharvesting complex II model membranes. Plant Cell. 2013;25(6):2155-70.

53. Wierzbicka MH, Przedpelska E, Ruzik R, Ouerdane L, Polec-Pawlak K, Jarosz M, Szpunar J, Szakiel A. Comparison of the toxicity and distribution of cadmium and lead in plant cells. Protoplasma. 2007;231(1-2):99-111.

54. Murchie EH, Lawson T. Chlorophyll fluorescence analysis: a guide to good practice and understanding some new applications. J Exp Bot. 2013;64(13):3983-98.

55. Suzuki K, Ohmori Y, Ratel E. High root temperature blocks both linear and cyclic electron transport in the dark during chilling of the leaves of rice seedlings. Plant Cell Physiol. 2011;52(9):1697-707.

56. Pfündel E, Klughammer C, Schreiber U. Monitoring the effects of reduced PS II antenna size on quantum yields of photosystems I and II using the DualPAM-100 measuring system. PAM Appl Notes. 2008;1:21-4

57. Myśliwa-Kurdziel, K. Strzałka: Influence of metals on biosynthesis of photosynthetic pigments. In: Physiology and Biochemistry of Metal Toxicity and Tolerance in Plants. Edited by K. PMNVaS. Dordrecht: Kluwer Academic Press; 2002: 201-227

58. Jones MR. Lipids in photosynthetic reaction centres: structural roles and functional holes. Prog Lipid Res. 2007:46(1):56-87.

59. Gruszecki Wl, Strzalka K. Carotenoids as modulators of lipid membrane physical properties. Biochim Biophys Acta. 2005;1740(2):108-15.

60. Ruban AV, Johnson MP. Xanthophylls as modulators of membrane protein function. Arch Biochem Biophys. 2010;504(1):78-85.

61. Andreeva A, Stoitchkova K, Busheva M, Apostolova E. Changes in the energy distribution between chlorophyll-protein complexes of thylakoid membranes from pea mutants with modified pigment content. J Photochem Photobiol, B. 2003;70(3):153-62.

62. Kovacs L, Damkjaer J, Kereiche S, llioaia C, Ruban AV, Boekema EJ, Jansson S, Horton P. Lack of the light-harvesting complex CP24 affects the structure and function of the grana membranes of higher plant chloroplasts. Plant Cell. 2006;18(11):3106-20.

63. Ruban AV, Young AJ, Horton P. Dynamic properties of the minor chlorophyll a/b binding proteins of photosystem II, an in vitro model for photoprotective energy dissipation in the photosynthetic membrane of green plants. Biochemistry. 1996;35(3):674-8.

64. Galvan-Arzate S, Santamaria A. Thallium toxicity. Toxicol Lett. 1998;99(1):1-13.

65. Krasnodębska-Ostręga B, Sadowska M, Wisniewska A. Speciation analysis of thallium in white mustard (sinapis alba I.) grown in the presence of thallium nitrate. In: Nriagu J, Pacyna J, Szefer P, Markert B, Wünschmann S, Namiesnik J, editors. Heavy Metals in the Environment Selected Papers from the ICHMET-15 Conference. Leiden: Maralte; 2012.

66. Fodor F. Physiological responses of vascular plants to heavy metals. In: PMNVaS K, editor. Physiology and Biochemistry of Metal Toxicity and Tolerance in Plants. Dordrecht: Kluwer Academic Press; 2002. p. 149-77.
67. Cosio C, Vollenweider P, Keller C. Localization and effects of cadmium in leaves of a cadmium-tolerant willow (Salix viminalis L.). Environ Exp Bot. 2006;58(1-3):64-74

68. Siemianowski O, Barabasz A, Weremczuk A, Ruszczynska A, Bulska E, Williams LE, Antosiewicz DM. Development of Zn-related necrosis in tobacco is enhanced by expressing AtHMA4 and depends on the apoplastic Zn levels. Plant Cell Environ. 2013;36(6):1093-104.

69. Krasnodębska-Ostręga B, Sadowska M, Ostrowska S: Thallium speciation in plant tissues-TI(III) found in Sinapis alba L. grown in soil polluted with tailing sediment containing thallium minerals. Talanta 2012, 93:326-329

70. Sorvari J, Sillanpaa M. Influence of metal complex formation on heavy metal and free EDTA and DTPA acute toxicity determined by Daphnia magna. Chemosphere. 1996;33(6):1119-27.

71. Pourahmad J, Eskandari MR, Daraei B. A comparison of hepatocyte cytotoxic mechanisms for thallium (I) and thallium (III). Environ Toxicol. 2010;25(5):456-67.

72. Villaverde MS, Hanzel CE, Verstraeten SV. In vitro interactions of thallium with components of the glutathione-dependent antioxidant defence system. Free Radic Res. 2004;38(9):977-84.

73. Hanzel CE, Verstraeten SV. Thallium induces hydrogen peroxide generation by impairing mitochondrial function. Toxicol Appl Pharmacol. 2006;216(3):485-92.

74. Korotkov SM, Emelyanova LV, Konovalova SA, Brailovskaya IV. TI(+) induces the permeability transition pore in $\mathrm{Ca}(2+)$-loaded rat liver mitochondria energized by glutamate and malate. Toxicol in Vitro. 2015;29(5):1034-41.

75. Garstka M, Drozak A, Rosiak M, Venema JH, Kierdaszuk B, Simeonova E, van Hasselt PR, Dobrucki J, Mostowska A. Light-dependent reversal of darkchilling induced changes in chloroplast structure and arrangement of chlorophyll-protein complexes in bean thylakoid membranes. Biochim Biophys Acta. 2005;1710(1):13-23.

76. Garstka M, Venema JH, Rumak I, Gieczewska K, Rosiak M, Koziol-Lipinska J, Kierdaszuk B, Vredenberg WJ, Mostowska A. Contrasting effect of darkchilling on chloroplast structure and arrangement of chlorophyll-protein complexes in pea and tomato: plants with a different susceptibility to nonfreezing temperature. Planta. 2007;226(5):1165-81.

77. Schreiber U. Pulse-Amplitude-Modulation (PAM) fluorometry and saturation pulse method: an overview. In: Chlorophyll a fluorescence A signature of photosynthesis Edited by Papageorgiou GC, Govindjee. Dordrecht: Springer; 2004. p. 279-319.

78. Baker NR, Oxborough K. Chlorophyll fluorescence as a probe of photosynthetic productivity. In: Chlorophyll a fluorescence A signature of photosynthesis Edited by Papageorgiou GC, Govindjee. Dordrecht: Springer; 2004. p. 65-82.

79. Rumak I, Gieczewska K, Kierdaszuk B, Gruszecki WI, Mostowska A, Mazur R, Garstka M. 3-D modelling of chloroplast structure under (Mg2+) magnesium ion treatment. Relationship between thylakoid membrane arrangement and stacking. Biochim Biophys Acta. 2010;1797(10):1736-48.

80. Minagawa J. State transitions-the molecular remodeling of photosynthetic supercomplexes that controls energy flow in the chloroplast. Biochim Biophys Acta. 2011;1807(8):897-905.

81. Pagliano C, Nield J, Marsano F, Pape T, Barera S, Saracco G, Barber J. Proteomic characterization and three-dimensional electron microscopy study of PSII-LHCII supercomplexes from higher plants. Biochim Biophys Acta. 2014;1837(9):1454-62.

82. Busch A, Hippler M. The structure and function of eukaryotic photosystem I. Biochim Biophys Acta. 2011;1807(8):864-77.

83. Kirchhoff H. Diffusion of molecules and macromolecules in thylakoid membranes. Biochim Biophys Acta. 2014;1837(4):495-502.

84. Joshi MK, Mohanty P. Chlorophyll a fluorescence as a probe of heavy metal ion toxicity in plants. In: Papageorgiou GC, Govindjee, editors. Chlorophyll a fluorescence A signature of photosynthesis. Dordrecht: Springer; 2004. p. 637-61.

85. Zubik M, Luchowski R, Puzio M, Janik E, Bednarska J, Grudzinski W, Gruszecki WI. The negative feedback molecular mechanism which regulates excitation level in the plant photosynthetic complex LHCIl: towards identification of the energy dissipative state. Biochim Biophys Acta. 2013;1827(3):355-64.

86. Derks A, Schaven K, Bruce D. Diverse mechanisms for photoprotection in photosynthesis. Dynamic regulation of photosystem II excitation in response to rapid environmental change. Biochim Biophys Acta. 2015; 1847(4-5):468-85. 